\title{
Osteogenesis Imperfecta
}

\author{
Roy Morello ${ }^{1,2}$ and Paul W. Esposito ${ }^{3,4}$ \\ ${ }^{1}$ Department of Physiology $\mathcal{E}$ Biophysics, \\ University of Arkansas for Medical Sciences, Little Rock, AR, \\ ${ }^{2}$ Division of Genetics, University of Arkansas for Medical Sciences, Little Rock, AR, \\ ${ }^{3}$ Department of Orthopaedic Surgery and Rehabilitation, \\ University of Nebraska Medical Center, \\ The Nebraska Medical Center, Omaha, NE, \\ ${ }^{4}$ Department of Orthopaedic Surgery, \\ Childrens Hospital and Medical Center, Omaha, NE, \\ USA
}

\section{Introduction}

Osteogenesis imperfecta (OI) is a congenital, generalized connective tissue disorder characterized by severe osteoporosis and bone fragility. Other features of the disease include dentinogenesis imperfecta, scoliosis, short stature, blue sclerae, hearing loss, and skin and ligament laxity (Cheung and Glorieux, 2008; Rauch and Glorieux, 2004). It is the most commonly inherited connective tissue disorder with a prevalence in the United States of about 25,000-50,000 cases (Martin and Shapiro, 2007). Molecular defects in type I collagen genes, COL1A1 and COL1A2, were first associated with OI in the early 1980's (Chu et al., 1983). Since then, although OI is most commonly an autosomal dominant disease, it became evident that in certain pedigrees with recurrence of OI in children of unaffected parents, other mechanisms of inheritance were at play. While germline mosaicism for a type I collagen mutation was demonstrated in some rare cases (Cohn et al., 1990; Edwards et al., 1992), in others where no collagen primary sequence defects were evident, the existence of recessively inherited forms of OI had to be postulated. It is known that $10-15 \%$ of all OI cases are not caused by type I collagen mutations and some of these can be distinguished from others based on specific bone histological features (Glorieux et al., 2002), clinical features (Glorieux et al., 2000), or because they are linked to a genetic region not containing type I collagen genes (Labuda et al., 2002). It took about a quarter of a century to identify the first gene responsible for some cases of recessive OI, i.e. CRTAP (encoding Cartilage-associated protein) (Morello et al., 2006). This initial discovery led the way to the identification of several novel genes whose mutations cause recessive forms of OI. It has rapidly become evident that while dominant forms of OI are caused by mutations in type I collagen genes, recessive forms of OI are almost always caused by mutations in genes encoding for proteins involved in the type I collagen synthetic pathway and often residing in the rough endoplasmic reticulum (rER). Thus, all direct and indirect collagen interactors, either in the rER or Golgi apparatus or involved in intracellular collagen 
trafficking, have become new candidates for recessive or atypical forms of OI. This chapter will provide the reader with an update on the latest developments in the OI field, including description of new genes causing OI, mechanisms of disease and novel therapeutic approaches.

\section{Classification of Ol, clinical features and differential diagnosis}

Osteogenesis imperfecta was classified several years ago into four types based on clinical, radiological and genetic features (Sillence, 1988; Sillence et al., 1979). Type II OI is the perinatal lethal form followed by types III, IV and I, in decreasing order of severity with type I OI being the mildest form. The mode of inheritance is not unique to each type with at least types II (further sub-classified into IIA, IIB and IIC) and III that could be inherited in a dominant or recessive fashion. More recently, out of the more heterogeneous group of type IV patients, novel types V, VI and VII OI were described based on unique clinical and/or histological features and linkage to loci where no type I collagen genes were mapped (Glorieux et al., 2000; Glorieux et al., 2002; Labuda et al., 2002).

The nosology of OI has been a subject of discussion and revision in light of recent discoveries of novel genes causing recessive forms of the disease. Plotkin (Plotkin, 2004) proposed to classify as OI all those cases in which a mutation in either COL1A1 or COL1A2 can be identified. Cases resulting from mutations in other genes would be classified as syndromes resembling OI. Others have proposed to adopt a revised Sillence classification of OI type I through VI but removing types VII and VIII which are due to mutations in CRTAP and LEPRE1, respectively, but have clinical and radiological features indistinguishable from types II-IV (Van Dijk et al., 2010). A more genetically oriented classification has also being proposed (Forlino et al., 2011). Here the classical Sillence OI types I-IV are maintained (all due to either COL1A1 or COL1A2 defects), followed by the previously described types V, VI and VII, and then in increasing order new types of OI (the latest is number XI) where each new type (from types $\mathrm{V}-\mathrm{XI}$ ) is due to a mutation in a different gene (Table 1). Conversely, the 2010 Revision of the Nosology and Classification of Genetic Skeletal Disorders (Warman et al., 2011) has agreed to retain the Sillence classification as the universally accepted way to classify the degree of OI severity but to free it from any direct molecular reference.

Because the original Sillence classification has been in use for over 30 years and instantly refers to the clinical severity of the disease, it is likely that physicians will continue to use it at least until the underlying genetic mutation of a patient has been clearly determined. The strictly genetic classification could be quite useful though as it is indeed possible that different genetic etiology and hence mechanism of disease may require a different therapeutic approach. This is beginning to emerge for instance in patients with SERPINF1 mutations who have not shown beneficial effects from bisphosphonate treatment (Homan et al., 2011).

Although there remains a great deal of difficulty making a definitive diagnosis in many of the children, recognition that there are recessive forms of osteogenesis imperfecta has clarified a historically confusing differential diagnosis. Utilization of these modified classifications also assists in identifying individuals without the classic types I - IV from normal children with nonaccidental trauma and other unrelated metabolic bone diseases. 


\begin{tabular}{|c|c|c|c|c|}
\hline $\begin{array}{l}\text { OI } \\
\text { type }\end{array}$ & Inheritance & Clinical features & Gene defect & Protein \\
\hline $\mathrm{I}$ & $\mathrm{AD}$ & Mild & COL1A1 (null alleles) & a1(I) \\
\hline II & $\mathrm{AD}$ & Lethal & COL1A1 or COL1A2 & a1(I) or a2(I) \\
\hline III & $\mathrm{AD}$ & Severe, deforming & COL1A1 or COL1A2 & a1(I) or a2(I) \\
\hline IV & $\mathrm{AD}$ & Moderate & COL1A1 or COL1A2 & a1(I) or a2(I) \\
\hline V & $\mathrm{AD}$ & $\begin{array}{l}\text { Hypertrophic callus, dense } \\
\text { metaphyseal band, } \\
\text { calcification of radio-ulnar } \\
\text { interosseus membrane }\end{array}$ & Unknown & Unknown \\
\hline VI & $\mathrm{AR}$ & $\begin{array}{c}\text { Severe: mineralization defect, } \\
\text { 'fish scale' bone lamellae, } \\
\text { slightly elevated AP }\end{array}$ & SERPINF1 & PEDF \\
\hline VII & $\mathrm{AR}$ & $\begin{array}{c}\text { Very severe to lethal, } \\
\text { rhyzomelia }\end{array}$ & CRTAP & CRTAP \\
\hline VIII & AR & Severe to lethal, rhyzomelia & LEPRE1 & P3H1 \\
\hline IX & $\mathrm{AR}$ & Moderate to severe & PPIB & CYPB \\
\hline$x$ & AR & Severe & SERPINH1 & HSP47 \\
\hline XI & AR & $\begin{array}{c}\text { Moderate to severe with joint } \\
\text { contractures } \\
\text { (Bruck syndrome 1?) }\end{array}$ & FKBP10 & FKBP10 \\
\hline $\mathrm{NC}$ & AR & $\begin{array}{c}\text { Moderate to severe with joint } \\
\text { contractures and pterygia, } \\
\text { Bruck syndrome } 2\end{array}$ & PLOD2 & LH2 \\
\hline $\mathrm{NC}$ & $\mathrm{AR}$ & $\begin{array}{c}\text { Ocular form of OI, } \\
\text { osteoporosis pseudoglioma } \\
\text { syndrome }\end{array}$ & LRP5 (null alleles) & LRP5 \\
\hline $\mathrm{NC}$ & AR & Moderate to severe & SP7 & OSX (Osterix) \\
\hline
\end{tabular}

Table 1. Genetic classification of $\mathrm{OI}(\mathrm{AD}=$ autosomal dominant; $\mathrm{AR}=$ autosomal recessive; $\mathrm{NC}=$ not classified)

Type I: These individuals typically do not have major bone deformity and have a significant variability in terms of number of fractures, even within the same family. Fractures typically begin when the children start to ambulate. Plain radiographs often are normal in appearance. These individuals may have blue sclera and hearing loss, although this may not occur before the second or third decade. Dentinogenesis imperfecta is not typically a major component of Type I. There may be subtle dental findings. There are no long-term studies to determine if the collagen defect might lead to later dental problems. Growth and stature are typically mildly decreased in type I OI (Forlino et al., 2011; Sillence et al., 1979).

Type II: Type II is historically described as perinatally lethal, typically from pulmonary failure related to the severe involvement of the chest cavity with small volume, deformity, and recurrent rib fractures. There may also be some involvement of the intrinsic collagen of the lung parenchyma (Forlino et al., 2011; Sillence et al., 1979).

These children are frequently diagnosed in prenatal ultrasounds with short, severely bowed long bones with multiple fractures. Radiographically, at the time of birth, they have severe 
bowing of the long bones, multiple fractures in different stages of healing, poorly defined cortices, and crumpling or wrinkling of the bones in an accordion-type fashion. There is poor tubulation with wide medullary canals. There is typically severe wedging deformity of the vertebrae. The skull is usually quite soft and large (Forlino et al., 2011; Sillence et al., 1979). Some of these children, including some treated with bisphosphonates, have survived for several years.

Type III: These patients are also frequently diagnosed on prenatal ultrasound. They also have relative shortening of the long bones, significant bowing, and multiple prenatal and postnatal fractures. These children continue to have fractures even with gentle handling. This is the most severe non-lethal form. They may have a very typical triangular facies, blue sclerae, dentinogenesis imperfecta, vertebral fractures, and frequently scoliosis. Without treatment with bisphosphonates, this OI type frequently demonstrates classic "popcorn epiphyses" of the long bones and patients have significant short stature (Forlino et al., 2011; Sillence et al., 1979).

Type IV: Traditionally, this classification has included children with phenotypes that did not fit into Sillence type I or III. These children typically have multiple fractures, varying degrees of deformity, as well as a great deal of variation in terms of color of the sclera, cranial settling, dentinogenesis imperfecta, and stature. With the recognition of recessive forms, many of these children previously classified as having type IV are now recognized as having one of these other, less common forms (Forlino et al., 2011; Sillence et al., 1979).

Type V: These individuals have increasing bone fragility and a moderately severe phenotype of OI. They also have calcification of the interosseous membrane which can be noted in the first year of life. This causes a significant decrease in pronation and supination. The radial head dislocates anteriorly, and long bone fracture can result in a very hypertrophic callus. There can be a radio-dense band at the end of the metaphysis. There is a unique mesh-like pattern of lamination histologically under polarizing light. (Arundel et al., 2011; Glorieux et al., 2000).

The clinical features of the recessive types of OI are described in section 4 (Molecular genetics of dominant and recessive OI).

\section{Management and treatment}

A team approach is vital to care for children with OI because many of them have not only recurrent fractures and severe bowing deformities, but also lax joints and connective tissueassociated problems. Long-term, individuals may develop other significant health issues, including cardiac, pulmonary, and joint problems. Unfortunately, to this point there is no good long-term data to determine what types of problems individuals with OI develop, their frequency, and appropriate treatment, or whether present medical management will improve long-term function. There is also very likely a significant difference in long-term function and the rate of deterioration that is dependent upon the specific genetic defect, but this has not been studied.

Bisphosphonates have been utilized extensively over the past decade in the treatment of osteogenesis imperfecta and other disorders with brittle bones and have been shown to clearly increase cortical thickness (Arikoski et al., 2004; Rauch and Glorieux, 2006). They improve comfort and function (Land et al., 2006a) but they do not lead pre-existing bony deformity and bowing to remodel (Astrom et al., 2007; Forin et al., 2005; Land et al., 2006a; Plotkin et al., 2006) (Figure 1). Decreases in fracture rates have been difficult to document. 
Centers that treat large numbers of these children however have anecdotally noted a marked increase in activity level and ambulation, even in children with severe type III OI. Present indications for treatment with bisphosphonates in children with the more severe forms of OI include marked bowing, which is interfering with comfort and function, and recurrent fractures (de Graaff et al., 2011; Forin et al., 2005; Glorieux, 2007; Glorieux et al., 1998; Plotkin et al., 2006; Rauch and Glorieux, 2006).
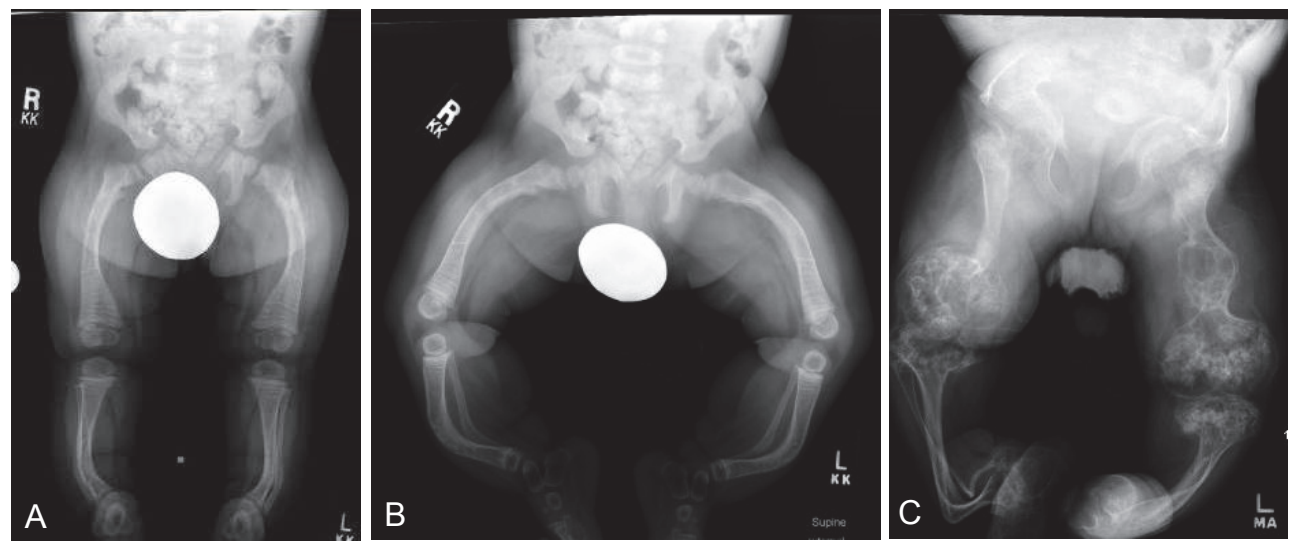

Fig. 1. A, B: 15-month old with type III OI. Note the relatively normal physis, and reasonable bone development following treatment with pamidronate since infancy. However, the significant bowing will not remodel, and as these children begin to pull up to stand they will predictably fracture at the apex of the bow. C: untreated 17 year old also with type III demonstrating popcorn epiphysis and signs of recurrent fractures.

The greatest improvement in areal bone density occurs in the first year of treatment. Pamidronate has been studied the most extensively, and has been shown to improve vertebral height and development in children with compressed vertebral bodies (Land et al., 2006b). Infants and young children with more severe OI with bowing and recurrent fractures have been safely treated with pamidronate (Astrom et al., 2007; Land et al., 2006a; Plotkin et al., 2006). The DEXA scan is the most frequent test utilized to help determine the relative severity of the OI, and the Z-score has ben utilized to monitor the response to treatment. However, there is not data suggesting that the goal of treatment is to develop a bone density in the normal range. At the present time, the clinical parameters of improved comfort, decreased fracture rate, and progression of normal developmental milestones offers the best clinical assessment of effective treatment. Zoledronic acid is a more potent bisphosphonate, which requires only one intra-venous treatment per year. It is presently being studied, but this data and results are not yet available (Shapiro and Sponsellor, 2009).

Initial treatment protocols with pamidronate were for a set number of years depending on the treating center. However, it has been noted that if the treatment is discontinued in a growing child, the bone that is developing at the proximal and distal end of the long bones is not treated. This gives rise to a stress riser between the treated bone of the shaft and the relatively soft bone at either end of the long bones (Breslau-Siderius et al., 1998; Rauch et al., 2006) . Theoretically, this is a concern with the longer acting agents, which may be given only 
once per year (Rauch et al., 2007; Rauch et al., 2006; Ward et al., 2007). The ideal treatment protocol is not universally agreed upon and it is recognized that other forms of treatment in the future will improve the lives of these individuals (Devogelaer and Coppin, 2006; Glorieux, 2007; Glorieux et al., 1998; Plotkin et al., 2006; Rauch and Glorieux, 2006).

There are a number of recent review papers dealing with the evaluation and treatment of osteogenesis imperfecta. These papers very nicely demonstrate the impact of the team approach, early medical management with bisphosphonates combined with prudent surgical management, address the questions that remain to be answered, and address the differences in approach between centers (Esposito and Plotkin, 2008; Forlino et al., 2011; Shapiro and Sponsellor, 2009).

It is less clear when to treat children with type I OI. Many centers recommend that treatment with bisphosphates be withheld unless the children are having recurrent fractures. Whether or not the bone density as measured on DEXA results as an isolated parameter has a role in determining treatment in this patient population with type I OI is unclear. Bone density has been correlated with disease severity, and may be predictive of long-term function (Plotkin et al., 2006).

The role of bisphosphonate treatment with non-union fractures is also unclear. Non-unions have been noted in $15 \%$ of children with osteogenesis imperfecta even prior to treatment with bisphosphonates (Agarwal and Joseph, 2005). There is one report of delay in healing following osteotomies but not fractures (Pizones et al., 2005). Non-unions have been reported post surgically (Cho et al., 2011). There are other reports that patients receiving bisphosphonates did not have issues with bone healing. El Sobky et al reported that children treated with pamidronate prior to surgery and afterwards function better than children treated with surgery alone (el-Sobky et al., 2006). In our experience with a large OI clinic population, when pamidronate is discontinued, some of the children have increased bone pain, which decreases after treatment is restored, and an increase in fracture rate, although this is not reported definitively in the literature.

Bisphosphonate treatment has clearly been shown to improve vertebral height even after significant wedge compression deformity of the vertebrae (Land et al., 2006b). However, there is no report of whether this treatment changes the incidence or severity of scoliosis. One recent spine $x$-ray review of a large osteogenesis imperfecta clinic population showed a significant increase in spondylolysis and spondylolisthesis above the incidence reported in otherwise normal children. The vast majority of these children had type III and type IV OI, and were ambulatory following treatment with bisphosphonates (Hatz et al., 2011). The long term implications are unclear.

\subsection{Surgical treatment}

Preoperative assessment and planning are critical to successful surgical outcomes in these individuals. The indications for surgical realignment include recurrent fractures and severe deformities in children with severe osteogenesis imperfecta who are making attempts to stand. Children with type I may also benefit from telescoping percutaneous intramedullary nailing to avoid the necessity of spica casting. Children with severe OI who sustained fractures in areas of pre-existing deformity very consistently have had increase in the deformity from muscle pull even though they are casted. This leads to a repetitive cycle of fracture and progressive deformity. The children with significant bowing who are beginning to stand will predictably fracture. This cycle of recurrent 
fracture very clearly interferes with their psychomotor development. There is rarely an indication for operative treatment prior to the children attempting to stand as most of the fractures are low energy and can be splinted for a brief period of time. Age is not necessarily a major factor in determining when to perform the surgery but may have an impact on the type of fixation utilized (Fassier et al., 2006; Fassier and Glorieux, 2003).Lower extremities are typically more severely involved than the upper extremities and interfere with psychomotor development more significantly than upper extremity deformities early in life. However, there are some children who benefit from upper extremity surgery, especially of the humerus, because of the use of arms for weight bearing to a much greater extent than their peers in the normal population (Amako et al., 2004; Gargan et al., 1996; Montpetit et al., 2003; Sulko and Radlo, 2005).

\subsection{Principles of surgery}

The goal of surgery in a child who is attempting to bear weight or has recurrent fractures, which interfere with his or her ability to ambulate comfortably even in a wheelchair, is to obtain anatomic mechanical alignment while load sharing with the bone and intramedullary device. Surgery should not be performed for deformity until bone density has been optimized medically. Fractures may require operative treatment prior to medical treatment if a child presents with a disabling injury and the surgeon's assessment is that the bone structure is adequate to allow for fixation. Ideally, this device will telescope and grow with the child. The principles include minimizing injury to the soft tissue envelope of the bone and to the adjacent joints. The most frequently utilized device is the Fassier-Duval nail, as this has been shown to be a safe and effective means of treatment and may increase the time to revision surgery (Esposito, 2010; Fassier et al., 2006; Turman et al., 2006). This device also decreases the need for arthrotomies. However, other intramedullary devices continue to be used with good results (Boutaud and Laville, 2004; Cho et al., 2007; Cho et al., 2011; Joseph et al., 2005; Luhmann et al., 1998). Treatment of younger children and toddlers may require earlier revision because the length of the rods are short initially because of the size and length of the child's one. However, the toddler years are a vital time of growth and development in the ability to stand, transfer, and ambulate. This technique also allows for the treatment of multiple bones simultaneously without the necessity of prolonged spica casting.

Osteotomies can be performed in the majority of children through a small incision percutaneously. This minimizes the injury to the soft tissue envelope and allows for some inherent rotational stability. The Fassier Duval technique also decreases the need for arthrotomies (Boutaud and Laville, 2004; Cho et al., 2007; Esposito, 2010; Fassier et al., 2006; Fassier and Glorieux, 2003; Joseph et al., 2005; Luhmann et al., 1998; Turman et al., 2006). Although most frequently utilized to correct femoral and tibial deformities, it is quite effective in the humerus (Figure 2A, B). There are specific deformities such as true coxa vara, which must be differientiated from the more common apparent coxa vara caused by anterolateral bowing of the proximal femoral diaphysis, which now can be effectively treated (Fassier and Glorieux, 2003). Femoral neck fractures can also be treated but the diaphysis must be protected with an intramedullary nail (Fassier and Glorieux, 2003; Tsang and Adedapo, 2011) (Figure 2C). True coxa vara can develop post surgical rodding but can also be seen to develop after trivial trauma or without known trauma. 

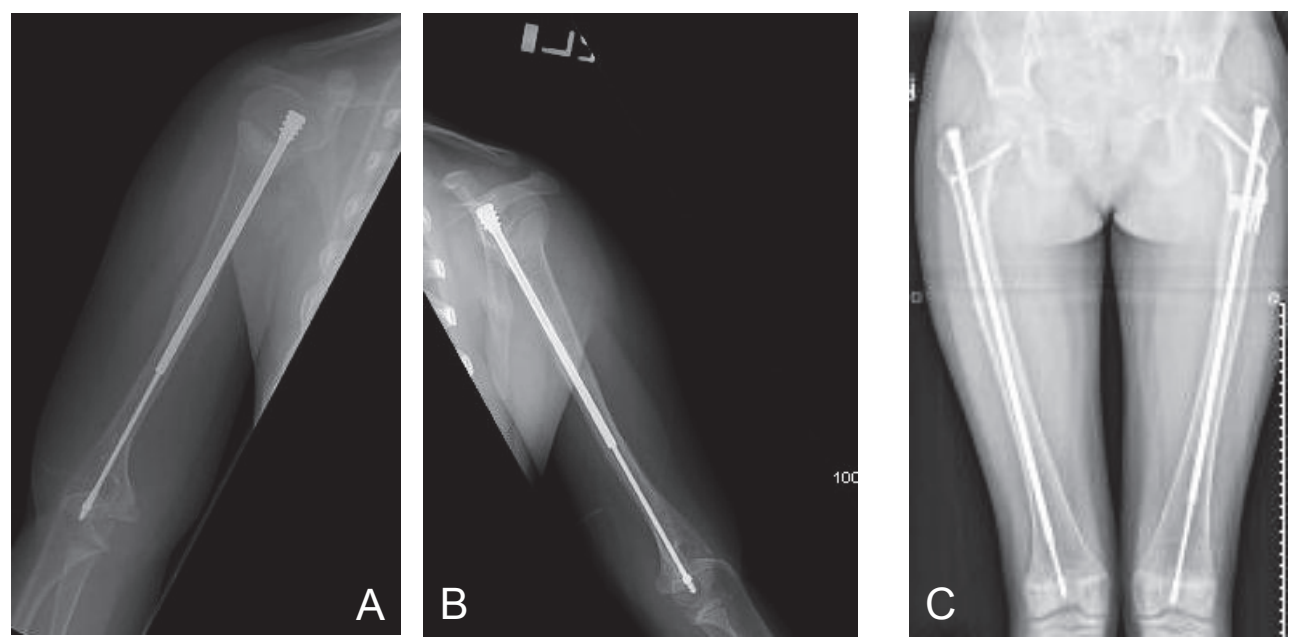

Fig. 2. A, B: 5-year old child with type III OI - 2 years post-op bilateral humeral osteotomies for recurrent fractures and severe bowing that were interfering with weight bearing function. C: 12 year old female with type I OI with sub-trochanteric fracture on the left and femoral neck fracture on the right side. The Fassier Duval percutaneous technique is not only useful in younger children with corrective osteotomies, but is very useful in dealing with adolescents with fractures. These children typically have small canals and need protection until at least skeletal maturity regardless of the age at initial surgery.

\subsection{Pitfalls}

Rigid devices should be avoided as some of the children will develop resorption of bone around the device because of this rigidity and stress shielding. Plates and screws not combined with an intramedullary device are stress risers and very clearly and predictably will develop bowing and fracture at the ends of the plates (Enright and Noonan, 2006).

Careful evaluation for associated problems such as cranial settling on the cervical spine must be undertaken (Forlino et al., 2011). Maintaining gentle longitudinal traction and supporting the neck greatly assists the anesthesiologist during intubation process and may prevent neurologic or bony spinal injury.

The majority of these children tend to have an elevated temperature because of their underlying metabolism. However, malignant hyperthermia is not associated with osteogenesis imperfecta. With the percutaneous techniques, significant bleeding is rarely encountered. However, when multiple bones are treated at one surgical setting, cumulative bleeding may necessitate transfusion.

The entire operative team must be educated in the care and handling of these children. It is not mandatory in all of the children to utilize an arterial line, monitor blood pressure, if they have been treated with bisphosphonates and had a good response to that treatment. Setting the blood pressure cuff to neonatal pressures only in children with reasonable bone density and structure can allow for safe monitoring. This is especially true if the cuff is placed over a bone that has previously had an intramedullary nail placed. Obviously in a child with severe bone weakness and deformity, an arterial line may be indicated. 
Post operative pain can be a difficult problem, with spasm necessitating treatment such as diazepam. Recent experience in one of our centers with epidural technique has shown that this can be done safely and has made a significant improvement in comfort and has enhanced post operative rehabilitation. Post operative casting or splinting is necessary only for a brief period of time if the surgeon determines that it is necessary to control rotation or to provide comfort. In some series and in our ongoing experience, splinting for 3-4 weeks is adequate. Protected weight-bearing can then begin, minimizing muscle atrophy, joint stiffness and osteoporosis from immobilization. Correcting as many deformities as necessary at one episode may decrease the number of fractures and total time of immobilization for these children.

\section{Molecular genetics of dominant and recessive $\mathrm{OI}$}

Osteogenesis imperfecta is commonly an autosomal dominant disease; however, about 10$15 \%$ of all OI cases are due to a recessively inherited mutation in a non-collagen coding gene.

\subsection{Dominant OI}

Dominant forms of osteogenesis imperfecta are always associated with mutations in the COL1A1 or COL1A2 gene encoding the a1(I) or a2(I) chain of type I collagen, respectively. COL1A1 mutations causing a reduced synthesis of type I collagen via haploinsufficiency are referred to as 'quantitative mutations' and usually result from nonsense substitutions or frameshifts that cause a premature termination codon and subsequent degradation of the transcript by the nonsense-mediated RNA degradation mechanism. These mutations typically result in mild forms of OI (i.e. type I OI) where each cell produces less collagen but of normal quality and structure. Patients with these mutations have short to normal stature, little to no deformities, bluish sclerae and increased susceptibility to fractures (Forlino et al., 2011; Rauch and Glorieux, 2004). In contrast, missense mutations in the a1(I) or a2(I) chain, especially glycine (Gly) substitutions in the Gly-X-Y repeat along the triple helical domain, as well as splice mutations causing in-frame deletions or exon skipping are usually referred to as 'qualitative or structural mutations' and cause lethal (OI type II), severe (type III), or moderate (type IV) disease. These mutations significantly impact the normal structure and assembly of the procollagen heterotrimer and may trigger a cascade of deleterious events at both the intracellular level, including abnormal collagen post-translational modification, folding, trafficking and ER-stress, and extracellular level, including reduced collagen in the matrix, abnormal mineralization and altered matrix-to-cell signaling. Although well over 1000 different dominant mutations in COL1A1 or COL1A2 have been described, it has been quite difficult to establish a genotype-phenotype correlation among the many different structural mutations and that could explain the spectrum of clinical severity ranging from moderate to lethal (Byers et al., 1991). Some general rules though have held true. 1) Because the trimer assembly and the winding of the triple helical domain proceed in a zipper-like manner from the $\mathrm{C}$ - terminus to the $\mathrm{N}$-terminus, mutations closer to the $\mathrm{C}$-terminus cause a more severe phenotype. 2) A greater proportion of lethal mutations affect the a1(I) versus the a2(I) chain. 3) One third of all Gly substitutions in the triple helical domain are lethal, especially when Gly is replaced by a charged or a branched side chain amino acid. 4) Two and eight lethal regions in the helical domain of a1(I) and a2(I), respectively, have been identified and align with major ligand binding sites such as those for integrins, matrix 
metalloproteinases and various matrix molecules including proteoglycans (for a review see (Marini et al., 2007)).

In conclusion, it is also important to remember that some rare mutations in either COL1A1 or COL1A2 can cause a form of Ehlers-Danlos syndrome (EDS) (reviewed in (Beighton et al., 1998)).

\subsection{Recessive OI due to mutations of Leprecan family members}

The recently identified family of proteins called Leprecans includes five members: cartilageassociated protein (CRTAP), synaptonemal complex 65 (SC65 or No55), prolyl 3hydroxylase 1 (P3H1 or Leprecan, encoded by the LEPRE1 gene), prolyl 3-hydroxylase 2 ( $\mathrm{P} 3 \mathrm{H} 2$, encoded by the LEPREL1 gene), and prolyl 3-hydroxylase 3 ( $\mathrm{P} 3 \mathrm{H} 3$, encoded by the LEPREL2 gene). Initial studies showed that Crtap loss of function in mice causes an osteochondrodysplasia characterized by short stature, kyphosis, shortening of the first segment of the limb (i.e. rhizomelia), and severe osteopenia (Morello et al., 2006). The osteoclast counts and function were normal with absence of a hyper-resorptive phenotype. However, bone histomorphometry showed functional osteoblast defects with reduced mineral apposition rate (MAR) hence, decreased bone formation rate (BFR). Osteoid surfaces and volumes were reduced and mineralization showed a shorter lag time. Transmission electron microscopy studies of mouse skin fibroblasts showed that type I collagen fibrils formed in the extracellular matrix although they had, on average, a significantly increased diameter. Although CRTAP has no enzymatic activity, it can bind to $\mathrm{P} 3 \mathrm{H} 1$ in the rough endoplasmic reticulum (rER) and somehow facilitate its activity. Biochemically, the Crtap-/- mouse phenotype is associated with lack of conversion of Pro 986 into the 3-hydroxy-proline normally found at that position in the triple helical domain of a1(I), a1(II) and a2(V) chains (Baldridge et al., 2010; Morello et al., 2006). Severely decreased CRTAP expression due to a hypomorphic mutation with residual expression of normal protein is associated with "rhizomelic" recessive osteogenesis imperfecta type VII, described by Ward et al. (Ward et al., 2002) in a unique First Nations Community pedigree of Northern Quebec. Instead, complete absence of CRTAP (mostly due to loss of function mutations) causes lethal to severe recessive OI in humans (Barnes et al., 2006; Morello et al., 2006). Although initially classified as type IIB-III, also these cases are tentatively classified as type VII OI. Because Crtap can form a trimeric complex (so called prolyl 3-hydroxylation complex) together with prolyl 3-hydroxylase 1 (P3h1, encoded by LEPRE1) and cyclophilin $\mathrm{B}$ (CypB, encoded by PPIB) (Morello et al., 2006) in the rER, the genes encoding these interactors became new candidates for causing recessive OI. Mutations in LEPRE1 were then identified in probands affected with recessive OI (tentatively classified as type VIII OI) and negative for mutations in COL1A1, COL1A2 or CRTAP (Cabral et al., 2007). It has been estimated that CRTAP and LEPRE1 mutations contribute to about 5 to $7 \%$ of all severe recessive OI cases (Barnes et al., 2010). This number may be higher in certain populations or geographic regions. In fact, recurrent pathogenetic LEPRE1 alleles have been described in populations of West African origin (Cabral et al., 2007) or Ireland (Irish Travelers) (Baldridge et al., 2008). Clinically, newborns with either CRTAP or LEPRE1 mutations are indistinguishable and characterized by multiple healing fractures, short tubular femurs due to lack of modeling, and extreme low bone mineralization (Baldridge et al., 2008; Marini et al., 2010; Willaert et al., 2009). Their sclerae are usually white. P3H1 is the enzyme responsible for the conversion of proline into 3-hydroxy-proline (3-Hyp) (Vranka et al., 
2004) and decreased/lack of this modification at Pro986 in the triple helical domain of type I collagen also characterizes these patients (Cabral et al., 2007). More recently, it was demonstrated that in tissues as well as fibroblast cultures, loss of CRTAP protein was associated with loss of $\mathrm{P} 3 \mathrm{H} 1$ protein and loss of $\mathrm{P} 3 \mathrm{H} 1$ was associated with loss of CRTAP (Baldridge et al., 2010; Chang et al., 2009; van Dijk et al., 2009). This evidence indicated that CRTAP is required for P3H1 stabilization and activity in vivo and vice versa, suggesting a common pathogenetic mechanism and thus providing an explanation for the very similar clinical findings in probands with mutations in these two genes. The generation of Lepre1 null mice was recently reported and the phenotype is highly similar to that of Crtap-/- mice (Vranka et al., 2010).

Further characterization of the phenotype of Crtap-/- mice demonstrated primary subtle defects in the lung and kidney with increased cell proliferation and also skin laxity with reduced thickness, stiffness, and overall strength (Baldridge et al., 2010). This is consistent with a generalized connective tissue disease, but it may also indicate the existence of a primary defect in the OI lung; respiratory distress and failure have been documented in OI patients with CRTAP or LEPRE1 mutations (Baldridge et al., 2008).

\subsection{Recessive Ol due to mutations of peptidyl-prolyl cis-trans isomerases}

At least three structurally distinct families of proteins have been linked by their ability to catalyze the bond preceding a proline residue between its cis and trans forms: the Cyclophilins (cyclosporine A binding proteins), the FKBPs (FK506-binding proteins), and the Parvulins (Gothel and Marahiel, 1999). The peptidyl-prolyl cis-trans isomerases (PPIase), also known as immunophilins, were initially identified as the intracellular receptors of the immunosuppressive drugs cyclosporine A and FK506/rapamycin (Gothel and Marahiel, 1999). They are widely distributed in all eukaryotes, prokaryotes and archaea and are present in all major cell compartments indicating that their function is required in several cellular processes. The cis-trans isomerization of peptidyl-prolyl bonds that they catalyze is a protein conformational change occurring during protein folding and thought to be rate limiting for type I collagen which contains about $20 \%$ proline residues (Gothel and Marahiel, 1999). Unlike most Cyclophilins which are predicted to localize either in the nuclear or cytosolic compartment, Cyclophilin B is localized in the ER (Pemberton and Kay, 2005) or secreted extracellularly (Yao et al., 2005). Because of its interaction with Crtap and P3h1 to form the prolyl 3-hydroxylation complex in the ER, Cyclophilin B became the next logical candidate potentially implicated in recessive forms of OI. Mutations in Ppib (encoding CypB) were first identified in hereditary equine regional dermal asthenia (HERDA) (Tryon et al., 2007), a recessive condition affecting Quarter Horses with features resembling those of Ehlers Danlos and Epidermolysis Bullosa syndromes. However, more recently PPIB mutations were also associated with recessive OI in three distinct families (Barnes et al., 2010; van Dijk et al., 2009). It is important to note that lack of PPIB causes shorter, undertubulated, bowed and fractured long bones but without rhizomelia. The degree of severity seems variable and is, perhaps, dependent upon the location of the mutations. One report described 4 probands with severe type IIB/III OI and frameshift mutations in either exon 4 or 5 (van Dijk et al., 2009), while another report described two siblings with a moderately severe OI who were able to reach independent ambulation. They had a mutation in the first coding triplet modifying the initial methionine into arginine with apparent lack of protein (Barnes et al., 2010). These patients are sometimes classified as having type IX OI. 
A controversy also exists regarding the modification status of type I collagen chains in probands' fibroblasts with PPIB mutations. Those affected with severe OI were shown to have over-modification of type I collagen chains and a significantly reduced level of Pro986 3hydroxylation (but higher than those observed in patients with mutations in either CRTAP or LEPRE1) (van Dijk et al., 2009) while those with moderate OI showed normal levels of collagen modification and prolyl 3-hydroxylation (Barnes et al., 2010). The description of additional families with $P P I B$ mutations will help to clarify this important aspect. Absence of Cyclophilin B only moderately affected expression levels of either CRTAP or P3H1 protein, indicating its higher degree of independence from the prolyl 3-hydroxylation complex (van Dijk et al., 2009). Due to the fact that the whole 3-hydroxylation complex was previously shown to possess, besides prolyl 3-hydroxylase and peptidyl-prolyl isomerase activity, a collagen chaperone function (Ishikawa et al., 2009), it is still unclear what independent contributions these activities have to the phenotype of OI when they are impaired. Mice deficient in Cyclophilin B have been shown to have severe recessive OI phenotype with collagen over-modification, absence of Pro ${ }^{986}$ 3-hydroxylation, and also reduced levels of P3h1 (Choi et al., 2009).

Mutations in a second immunophilin molecule, called FKBP65/FKBP10 (encoded by the FKBP10 gene), have been initially detected in a few Turkish families and a MexicanAmerican family (Alanay et al., 2010). FKBP65 resides in the rough ER and is a protein known to interact with nascent matrix molecules, including tropoelastin and type I collagen, and have a molecular chaperone activity (Ishikawa et al., 2008; Patterson et al., 2005). Patients with mutations in FKBP10 were described as having a progressive severe form of OI. Born with normal length and weight, they had an early history of long bone fractures leading to progressive deformities of the limbs and eventually were wheelchair bound. Progressive kyphoscoliosis with flattening and wedging of the vertebral bodies is a distinctive feature of this recessive form of OI with absence of dentinogenesis imperfecta or hearing loss (Alanay et al., 2010). The procollagen chains synthesized by these patients' fibroblasts were not over-modified and prolyl 3-hydroxylation of Pro986 was normal, suggesting a downstream defect in the collagen synthetic pathway compared to this earlier modification. Further analyses showed a delayed secretion of type I collagen chains with dilation of the rER and evidence of abnormal intracellular collagen trafficking (Alanay et al., 2010). A second report described additional mutations in FKBP10 in patients affected with a recessive form of OI who also had contractures of the large joints, thus reminiscent of Bruck syndrome (Kelley et al., 2011). FKBP10 maps on chromosome 17q21 and further investigations are required to understand if $F K B P 10$ is indeed the causative gene for Bruck syndrome type I (recessive OI with large joint contractures -MIM ID\#259450) whose critical region, however, had been originally mapped to 17p12 (Bank et al., 1999). These patients are sometimes classified as having type XI OI.

\subsection{Recessive Ol due to mutations of Serpin family members}

The Serpins (serine protease inhibitors) constitute a very large and broadly distributed superfamily of protease inhibitors which can be further subdivided into 16 clades (Law et al., 2006). They are thought to be important regulators of enzymes involved in proteolytic cascades and their role in human disease has clearly emerged (Roussel et al., 2011). Although grouped under the same superfamily due to sequence homology and common protein structure, two distinct groups can be identified: the first comprises the predominant 
family of protease inhibitors in mammals and is involved in the modulation of extracellular matrix remodeling, inflammation, and blood clotting (van Gent et al., 2003); the second includes a number of proteins without protease inhibitor activity and with a diverse array of functions, including molecular chaperones. Within the 36 identified human serpins, both HSP47 (heat-shock protein 47 or serpin peptidase inhibitor, clade $\mathrm{H}$, member 1 encoded by the SERPINH1 gene) and PEDF (pigment epithelium derived factor or serpin peptidase inhibitor, clade F, member 1 encoded by the SERPINF1 gene) belong to this second group of proteins and have been linked to recessive OI.

At present, one single proband with severe recessive OI was found to have a homozygous missense mutation in the SERPINH1 gene, encoding the collagen chaperone molecule HSP47 (Christiansen et al., 2010). Mutations in the Serpinh1 gene had been described earlier in a dog breed affected with OI (Drogemuller et al., 2009) while Serpinh1-null mice die in utero with multiple collagens defects (Nagai et al., 2000). The proband was born with typical OI features with generalized osteopenia, thin ribs with healing fractures, blue sclerae, dentinogenesis imperfecta, platyspondyly, short limbs with bowed femora, joint laxity, and relative macrocephaly. Additional complications included respiratory distress, pyloric stenosis, renal stones, hypotonia; he died at the age of 3 years and 6 months due to sudden respiratory failure (Christiansen et al., 2010). Similar to what was described with mutations in FKBP10, type I procollagen chains were not over-modified and were normally prolyl 3hydroxylated. However, they were noticed to accumulate in the Golgi apparatus and to be more susceptible to protease digestion, indicating a compromised helical structure. It appears that HSP47 may play a monitoring function for proper triple helical structure assembly and, like FKBP65, acts downstream of the prolyl 3-hydroxylation complex (Christiansen et al., 2010). This was tentatively classified as type X OI.

Recently mutations in SERPINF1, encoding the pigment epithelium derived factor (PEDF) have been identified in a few cases of recessive OI some of which were originally classified as OI type VI (Becker et al., 2011; Glorieux et al., 2002; Homan et al., 2011). Clinically these patients are born of normal weight and length, without fractures, limb deformities or joint laxity, with gray-white sclerae and normal facial features. Biochemically, they are characterized by a slight elevation in serum alkaline phosphatase and bone turn-over and by the absence of circulating levels of PEDF. They can begin to fracture early (before the first year of life) and progress to experience several other fractures which result in bone deformities and usually lack or loss of ambulation. The progressive worsening of the symptoms suggests a post-natal early onset of the skeletal phenotype; importantly, at the histological level, iliac bone biopsies show a large amount of un-mineralized osteoid on their cancellous bone due to a mineralization defect and a 'fish-scale' pattern of bone deposition instead of normal bone lamellation (Glorieux et al., 2002; Homan et al., 2011). All patients identified were homozygous for either nonsense mutations or frameshift mutations leading to a premature termination codon and likely to nonsense-mediated RNA decay, resulting in null alleles. Of note, PEDF-deficient mice were described earlier and showed increased stromal vessels and epithelial cell hyperplasia in both the prostate and pancreas (Doll et al., 2003). PEDF has been described as a multi-functional protein with roles as a potent inhibitor of angiogenesis, neurotrophic factor and collagen-interacting molecule among others (Dawson et al., 1999; Filleur et al., 2009; Meyer et al., 2002). It is a protein circulating in serum and the pathogenetic mechanisms leading to forms of recessive OI are currently unclear. This adds an exciting puzzle to solve about its multiple functions. 


\subsection{Recessive Ol due to mutations of other genes}

A second locus responsible for recessive OI with joint contractures (Bruck syndrome type II -MIM ID \#609220) had been previously identified and mapped at 3q23-q24 (van der Slot et al., 2003). Probands had a combination of OI and arthrogryposis, showing osteoporosis, long bone deformities, scoliosis and congenital joint contractures (Breslau-Siderius et al., 1998; Ha-Vinh et al., 2004). Mutations in the PLOD2 gene, encoding the lysyl-hydroxylase 2 enzyme which is a collagen telopeptide lysyl hydroxylase, were identified in 2003 (van der Slot et al., 2003).

The ocular form of OI is a recessive condition causing very low bone mass with fractures and severe eye defects that can lead to early blindness. These include hyperplasia of the vitreous, corneal opacity, secondary glaucoma, and the formation of retrolental masses resembling a retinoblastoma (Beighton et al., 1985; De Paepe et al., 1993). It was later recognized as the osteoporosis pseudoglioma syndrome (OPPG) (Beighton, 1986; Brude, 1986; Frontali and Dallapiccola, 1986; Superti-Furga et al., 1986). The OPPG locus was linked to the long arm of chromosome 11 (Gong et al., 1996) and the gene responsible for the disease was later identified as the LDL-receptor related protein 5 or LRP5 (Gong et al., 2001). LRP5 is an important regulator of bone mass accrual during growth and a co-receptor in the canonical Wnt pathway: null mutations cause OPPG while heterozygous carriers have also low bone mass (Gong et al., 2001). In addition, several missense mutations in the LRP5 gene have been associated with other conditions such as recessive and dominant familial exudative vitreoretinopathy 4 (Jiao et al., 2004; Toomes et al., 2004), and high bone mass phenotypes (Boyden et al., 2002; Little et al., 2002; Van Wesenbeeck et al., 2003).

\begin{tabular}{|l|c|c|c|c|c|c|c|}
\hline & SERPINF1 & CRTAP & LEPRE1 & PPIB & SERPINH1 & FKBP10 & PLOD2 \\
\hline $\begin{array}{l}\text { Dentinogenesis } \\
\text { Imperfecta }\end{array}$ & & $+/-$ & & & + & & \\
\hline Rhizomelia & & + & + & & & & \\
\hline Coxa vara & + & + & & & & + & \\
\hline $\begin{array}{l}\text { Femur } \\
\text { undertubulation }\end{array}$ & & + & + & + & & & \\
\hline Popcorn epiphyses & + & $+/-$ & $+/-$ & & & & \\
\hline Scoliosis & + & + & + & + & + & + & + \\
\hline Platyspondyly & & & + & & & & \\
\hline Vertebral wedging & & & & & & + & \\
\hline Ligamentous laxity & & + & + & + & + & + & \\
\hline Joint contractures & & & & & & + & + \\
\hline Wormian bones & & + & + & & & + & + \\
\hline $\begin{array}{l}\text { White/Grey/Blue } \\
\text { sclerae }\end{array}$ & $\mathrm{W} / \mathrm{B} / \mathrm{G}$ & $\mathrm{W} / \mathrm{G}$ & $\mathrm{W} / \mathrm{G} / \mathrm{B}$ & $\mathrm{W} / \mathrm{B}$ & $\mathrm{B}$ & $\mathrm{W} / \mathrm{G} / \mathrm{B}$ & $\mathrm{W} / \mathrm{G} / \mathrm{B}$ \\
\hline Proptosis & & + & & + & & & \\
\hline Respirat. distress & & + & + & & + & & \\
\hline Pterygia & & & & & & + & + \\
\hline Skin blisters & & & & & + & + & \\
\hline Elev. alkal. phosp. & + & & & & & & \\
\hline
\end{tabular}

Table 2. Tentative table for the differential diagnosis of recessive OI forms (+/- may or may not be present). 
Finally, in a unique patient diagnosed with OI a homozygous single base pair deletion causing a frameshift and a premature termination codon in the gene SP7/OSX encoding the transcription factor Osterix was described (Lapunzina et al.). The mutation eliminates the last of three zinc-finger DNA binding domains at the C-terminus of Osterix, likely affecting its transactivation function. In mice, Osterix is an essential transcription factor for proper osteoblast lineage differentiation and directly or indirectly activates the expression of a host of osteoblast genes beyond type I collagen. As a result, considering the importance of Osterix for murine skeletal development and homeostasis (Nakashima et al., 2002; Zhou et al., 2010), this finding was rather surprising because the predicted human phenotype would have been possibly even more dramatic than seen in the described proband. However, the molecular consequences and the mechanism behind the emergence of an OI phenotype due to OSX mutations are completely unknown, and the description of additional patients with OSX mutations will facilitate an understanding of the inherent pathogenetic process.

A list of clinical features identified in different forms of recessive OI is presented in Table 2.

\section{Mouse models of OI}

Different mouse models showing many of the clinical features of OI have been identified or generated in the past years. The phenotype severity of each model has been compared to the severity of human OI as classified by Sillence (Sillence et al., 1979).

\subsection{Mouse models due to alterations of type I collagen genes}

One of the most commonly utilized OI mouse models is the oim mouse (osteogenesis imperfecta murine) (Chipman et al., 1993). This is a naturally occurring strain of mice with a spontaneous nucleotide deletion in the Col1a2 gene that results in a frameshift and the alteration of the a2(I) procollagen C-propeptide. The phenotype is recessively inherited and homozygous mutant mice have osteopenia, small body size, limb deformity and skeletal fractures; it mimics a moderate to severe human OI and thus considered a model for OI type III. Interestingly, tissues of homozygous mutant mice accumulate a1(I) homotrimers.

The Mov13 mouse was instead generated by the germline insertion of Moloney murine leukemia virus (MMLV) into intron 1 of Col1a1 (Breindl et al., 1984; Jaenisch et al., 1983; Schnieke et al., 1983). The retroviral insertion blocks the initiation of transcription and inactivates the Col1a1 allele (Hartung et al., 1986). The insertion is lethal at midgestation in homozygous mice (comparable to a type II OI though causing earlier lethality) while heterozygous mice are viable and constitute a model for the mild type I OI with increased skeletal fragility but also interesting adaptations that lead to improved cortical mechanical properties (Bonadio et al., 1993).

The use of Cre-lox recombination technology made it possible to obtain the first knock-in mouse model for OI. An allele harboring a G to T transversion (nt 1546) and causing an a1(I) Gly ${ }^{349}$ to Cys substitution that was initially identified in a type IV OI patient was generated (Forlino et al., 1999). Heterozygous mice with this mutation, named Brittle IV (BrtlIV), express a tissue-specific balanced ratio of normal and mutant allele, have a dominant phenotype and moderately severe skeletal phenotype comparable to a human type IV OI; hence they represent a suitable model for the study of the pathophysiology of OI. They showed bone deformity, osteopenia, fragility and disorganized trabecular structure with phenotypic variability that goes from perinatal lethality to long term survival (Forlino et al., 
1999). The phenotypic variability was shown to be dependent on the differential expression of both extracellular and intracellular proteins (Forlino et al., 2007). Also the BrtlIV mouse model undergoes post-pubertal adaptations that increase femoral strength and stiffness perhaps by improvement of bone matrix material properties (Kozloff et al., 2004). Interestingly, homozygous BrtlIV mice carrying the single base pair substitution on both Col1a1 alleles have a near normal phenotype without fractures or altered bone mineral density (Forlino and al., 2005). The mechanism behind this phenomenon is currently poorly understood.

Other mice bearing point mutations in the Col1a1 gene were generated. These, for instance, include transgenic mice with specific substitution of Gly859 into either Cys or Arg and resulting in a dominant lethal phenotype (Stacey et al., 1988). Mice with an ENUmutagenesis induced frameshift mutation in the C-terminal domain of Col1a1 (named Aga2 from abnormal gait 2). The phenotype of these mice was dominant with decreased bone mass, fractures, early lethality, increased bone turnover and intracellular accumulation of abnormal procollagen chains that triggered an endoplasmic reticulum-associated stress response and osteoblast apoptosis (Lisse et al., 2008). Or transgenic mice carrying a minigene version of the human COL1A1 gene and reproducing a lethal in-frame deletion identified in an OI patient (Khillan et al., 1991; Pereira et al., 1993).

\subsection{Mouse models due to alterations of other genes}

The fragilitas ossium (fro/fro) mouse is a model for recessively inherited OI and was generated by treatment of mice with a chemical mutagen (Guenet et al., 1981). A high percentage of mutant pups die in the perinatal period with radiographic findings similar to a severe recessive OI type II. The surviving mice have progressive deformity but reduced fracture frequency (Sillence et al., 1993). The underlying mutation is a deletion in the sphingomyelin phosphodiesterase 3 (Smpd3) gene (Aubin et al., 2005) which was recently shown to be a positive regulator of mineralization in in vitro osteoblast cultures (Khavandgar et al., 2011).

Mice carrying genetically engineered mutations in Crtap, Lepre1 and Ppib genes encoding the components of the rER heterotrimeric prolyl 3-hydroxylation complex (namely cartilageassociated protein, prolyl 3-hydroxylase 1 and cyclophilin B, respectively) have been generated (Choi et al., 2009; Morello et al., 2006; Vranka et al., 2010). Their phenotype is very similar with severe osteopenia, kyphosis, skin laxity, abnormal collagen fibrils at the ultrastructural level and lack of collagen prolyl 3-hydroxylation (see more details on the phenotypes of these mice in the paragraph on Molecular Genetics of OI). They represent useful models for the study of recessively inherited OI and great tools for understanding its pathophysiology.

\section{Pathogenesis and disease mechanisms in OI}

As discussed above, COL1A1 null alleles cause dominant OI through a mechanism of haploinsufficiency whereby about half normal type I collagen trimers are secreted in the extracellular matrix causing a decreased bone mass and an osteoporotic phenotype (Willing et al., 1992). Contrary to homozygous COL1A1 null mutations that are most likely incompatible with life as seen in the Mov13 mice, patients with homozygous COL1A2 null mutations have a phenotype more similar to EDS (Malfait et al., 2006; Nicholls et al., 2001; 
Schwarze et al., 2004). They synthesize $a(I)_{3}$ homotrimers which were shown to be overmodified, to alter the triple helical structure and to resist collagenases digestion (Deak et al., 1985; Han et al., 2010; Kuznetsova et al., 2001).

Collagen structural mutations instead often have a profound impact on procollagen chains register and assembly and may slow down the winding of the triple helix resulting in overmodification of additional proline and lysine residues by ER resident enzymes (i.e. prolyland lysyl-hydroxylases). In addition, an increase in hydroxylysines can generate an abnormal glycosylation and intra/inter-molecular crosslink pattern in the collagen fibril (Kivirikko and Pihlajaniemi, 1998). The deceleration of collagen synthesis results in slower secretion and accumulation of misfolded procollagen chains in the ER. Indeed OI can be considered a conformational disease where stable misfolded procollagen chains assume a dominant negative effect. Importantly, depending on the location and the effect of the individual mutation the cellular response is different. Those mutations (e.g. those in the Cterminal propeptide) that interfere with chains association trigger an unfolded protein response (UPR) and target the misfolded polypeptides to proteosomes via the ER-associated degradation pathway (Chessler et al., 1993; Ishida et al., 2009; Lisse et al., 2008). Whereas mutations localized in the triple helix cause only regional misfolding, do not activate the UPR but rather autophagy and the autophagic elimination of these stable collagen aggregates (Bateman et al., 2009; Ishida et al., 2009; Makareeva et al., 2011). The overall cellular consequences of the activation of either pathway are likely to have a significant chronic effect on multiple osteoblast functions (Rutkowski et al., 2006; Tsang et al., 2010).

At the extracellular level, there is an alteration in the quality and quantity of secreted collagen. This causes an imbalance in the stoichiometry of matrix components (Fedarko et al., 1995) and altered interactions between collagen and non-collagenous proteins and between collagen and substrate adhesion molecules (e.g. integrins) (Marini et al., 2007). The changes in the matrix and its components affect the mineralization process and, irrespective of the type I collagen mutation, cause a shift towards increased mineralization density (Bateman et al., 2009; Camacho et al., 1996; Roschger et al., 2008a; Roschger et al., 2008b).

Based on recent findings, it has become clear that recessive OI can be caused by mutations in genes encoding collagen modifier molecules such as prolyl- or lysyl-hydroxylases, prolyl isomerases, collagen specific chaperones, and also 'adapter proteins' such as CRTAP. Loss of function of the prolyl 3-hydroxylation complex caused by mutations in CRTAP, LEPRE1, or $P P I B$ causes early post-translational defects in the procollagen synthesis, slowing down the triple helical winding with over-modification of prolyl and lysyl residues. With one exception (Barnes et al., 2010), the OI phenotype resulting from loss of function of these genes is almost invariably lethal to severe and comparable to a type II/III OI according to the original Sillence classification. Mutations in either FKBP10 or SERPINH1 do not cause procollagen chain over-modification and do not interfere with prolyl 3-hydroxylation, but somehow they affect collagen transport between the rER and Golgi. Thus, their effect on procollagen appears to be downstream of the prolyl 3-hydroxylation complex, but the resulting OI phenotype is still quite severe and similar to a type III/IV OI. Mutations in both PLOD2 (Bruck syndrome type II) and FKBP10 genes also cause joint contractures suggesting, perhaps, a potential interaction between their encoded proteins. It is still unknown how SP7/OSX mutations cause OI other than the simple consideration that type I collagen is a target of OSX and, therefore, may be down-regulated with impaired OSX function. 
With a few exceptions, the effects that mutations in genes causing recessive OI have on bone quality and bone matrix mineralization is still unclear. While in all cases there is severe osteopenia, mouse models for Crtap, Lepre1 and Ppib lack of function have overmodified collagen lacking 3-Hyp at Pro986, increased diameter of collagen fibrils, and decreased irregular deposition of ECM (Choi et al., 2009; Morello et al., 2006; Vranka et al., 2010). Fibroblasts from a patient with null CRTAP mutation were recently shown to depose less collagen in the matrix (Valli et al., 2011). Quantitative backscattered electron imaging studies on Crtap-null as well as OI-VII bones to determine bone mineralization density distribution have shown a higher calcium content of the bone matrix (Fratzl-Zelman et al., 2010); these results are similar to what has been observed in classical OI due to mutations in type I collagen genes (Boyde et al., 1999; Roschger et al., 2008a). In addition, those studies suggested altered mineralization kinetics resulting in an elevated tissue mineralization density (Fratzl-Zelman et al., 2010). Taken together these data suggest that any alteration in collagen structure or its post-translational modification may result in abnormal protein and mineral stoichiometry and likely abnormal mineralization kinetics.

However, among the different recessive forms of OI, OI VI (due to mutations in SERPINF1) shows a unique mineralization defect with persistence of non-mineralized osteoid on the cancellous bone and indicating a different pathogenetic mechanism (Homan et al., 2011).

\section{Conclusion}

Mutations affecting a specific collagen chain have a primary impact on tissues with higher expression of that chain (e.g. bone for COL1A1 or COL1A2, blood vessels for COL3A1, skin for COL7A1, etc...), and cause milder connective tissue abnormalities in tissues which express lower levels. These are usually dominant mutations. Instead, mutations affecting collagen modifying proteins in the rER or Golgi, or those involved in collagen intracellular transport, usually cause recessive conditions; clinically these can be even more severe than the former because they have an impact on multiple collagen chains based on the collagen chain substrate specificity of the modification being affected. Importantly, the biological relevance of that modification will emerge in the most severely affected tissue(s). Hence, the clinical signs of mutations in genes encoding either one of the collagen chains or one of the collagen modifying proteins often share many similarities and contribute to generate the disease spectrum that goes from Osteogenesis Imperfecta to Bruck to Ehlers Danlos to Epidermolysis Bullosa syndromes (see Table 2). A careful assessment of the proband's clinical features may provide essential hints toward the underlying molecular defect (e.g. joint contractures in case of PLOD2 or FKBP10 mutations), the correct diagnosis and the proper therapy and follow-up.

Additional cases of recessive OI are waiting further elucidation to uncover the yet unidentified culprit genes. With the discovery of new genes involved in skeletal dysplasias, and specifically OI, our understanding of the underlying pathogenetic processes will continue to improve as well as our ability to devise and then test new therapeutic approaches.

At the present time, the ability to care for these individuals, by combining the benefits of early bisphosphonate treatment with appropriate surgical techniques, has greatly enhanced the comfort and function of these children. Minimizing the soft tissue trauma associated with surgery and avoiding long-term and recurrent episodes of immobilization is also a 
major advance in recent years. Questions clearly remain with regard to the long-term implications of the medical and surgical treatments, as well as how to transition treatment as the children mature. Clearly, this is an interim approach and the advances in the genetic and molecular understanding of these disorders will lead to more appropriate and effective treatment of the underlying disease.

\section{Acknowledgements}

The authors would like to thank Dr. Michael Jennings (University of Arkansas for Medical Sciences, Little Rock, AR) and Linda Kraut (University of Nebraska, Omaha, NE) for editorial assistance. This work was supported in part by the Arkansas Biosciences Institute, the major research component of the Arkansas Tobacco Settlement Proceeds Act of 2000 (RM). Additional research support was obtained from the William R. Patrick Foundation (PWE).

\section{References}

Agarwal, V., and Joseph, B. (2005). Non-union in osteogenesis imperfecta. Journal of pediatric orthopaedics Part B / European Paediatric Orthopaedic Society, Pediatric Orthopaedic Society of North America 14, 451-455.

Alanay, Y., Avaygan, H., Camacho, N., Utine, G.E., Boduroglu, K., Aktas, D., Alikasifoglu, M., Tuncbilek, E., Orhan, D., Bakar, F.T., et al. (2010). Mutations in the gene encoding the RER protein FKBP65 cause autosomal-recessive osteogenesis imperfecta. American journal of human genetics 86, 551-559.

Amako, M., Fassier, F., Hamdy, R.C., Aarabi, M., Montpetit, K., and Glorieux, F.H. (2004). Functional analysis of upper limb deformities in osteogenesis imperfecta. J Pediatr Orthop 24, 689-694.

Arikoski, P., Silverwood, B., Tillmann, V., and Bishop, N.J. (2004). Intravenous pamidronate treatment in children with moderate to severe osteogenesis imperfecta: assessment of indices of dual-energy X-ray absorptiometry and bone metabolic markers during the first year of therapy. Bone 34, 539-546.

Arundel, P., Offiah, A., and Bishop, N.J. (2011). Evolution of the radiographic appearance of the metaphyses over the first year of life in type $\mathrm{V}$ osteogenesis imperfecta: clues to pathogenesis. Journal of bone and mineral research : the official journal of the American Society for Bone and Mineral Research 26, 894-898.

Astrom, E., Jorulf, H., and Soderhall, S. (2007). Intravenous pamidronate treatment of infants with severe osteogenesis imperfecta. Arch Dis Child 92, 332-338.

Aubin, I., Adams, C.P., Opsahl, S., Septier, D., Bishop, C.E., Auge, N., Salvayre, R., NegreSalvayre, A., Goldberg, M., Guenet, J.L., et al. (2005). A deletion in the gene encoding sphingomyelin phosphodiesterase $3(\mathrm{Smpd} 3)$ results in osteogenesis and dentinogenesis imperfecta in the mouse. Nature genetics 37, 803-805.

Baldridge, D., Lennington, J., Weis, M., Homan, E.P., Jiang, M.M., Munivez, E., Keene, D.R., Hogue, W.R., Pyott, S., Byers, P.H., et al. (2010). Generalized connective tissue disease in Crtap-/- mouse. PloS one 5, e10560. 
Baldridge, D., Schwarze, U., Morello, R., Lennington, J., Bertin, T.K., Pace, J.M., Pepin, M.G., Weis, M., Eyre, D.R., Walsh, J., et al. (2008). CRTAP and LEPRE1 mutations in recessive osteogenesis imperfecta. Human mutation 29, 1435-1442.

Bank, R.A., Robins, S.P., Wijmenga, C., Breslau-Siderius, L.J., Bardoel, A.F., van der Sluijs, H.A., Pruijs, H.E., and TeKoppele, J.M. (1999). Defective collagen crosslinking in bone, but not in ligament or cartilage, in Bruck syndrome: indications for a bonespecific telopeptide lysyl hydroxylase on chromosome 17. Proc Natl Acad Sci U S A 96, 1054-1058.

Barnes, A.M., Carter, E.M., Cabral, W.A., Weis, M., Chang, W., Makareeva, E., Leikin, S., Rotimi, C.N., Eyre, D.R., Raggio, C.L., et al. (2010). Lack of cyclophilin B in osteogenesis imperfecta with normal collagen folding. The New England journal of medicine 362, 521-528.

Barnes, A.M., Chang, W., Morello, R., Cabral, W.A., Weis, M., Eyre, D.R., Leikin, S., Makareeva, E., Kuznetsova, N., Uveges, T.E., et al. (2006). Deficiency of cartilageassociated protein in recessive lethal osteogenesis imperfecta. The New England journal of medicine 355, 2757-2764.

Bateman, J.F., Boot-Handford, R.P., and Lamande, S.R. (2009). Genetic diseases of connective tissues: cellular and extracellular effects of ECM mutations. Nat Rev Genet 10, 173183.

Becker, J., Semler, O., Gilissen, C., Li, Y., Bolz, H.J., Giunta, C., Bergmann, C., Rohrbach, M., Koerber, F., Zimmermann, K., et al. (2011). Exome sequencing identifies truncating mutations in human SERPINF1 in autosomal-recessive osteogenesis imperfecta. American journal of human genetics 88, 362-371.

Beighton, P. (1986). Osteoporosis-pseudoglioma syndrome. Clin Genet 29, 263.

Beighton, P., De Paepe, A., Steinmann, B., Tsipouras, P., and Wenstrup, R.J. (1998). EhlersDanlos syndromes: revised nosology, Villefranche, 1997. Ehlers-Danlos National Foundation (USA) and Ehlers-Danlos Support Group (UK). American journal of medical genetics 77, 31-37.

Beighton, P., Winship, I., and Behari, D. (1985). The ocular form of osteogenesis imperfecta: a new autosomal recessive syndrome. Clin Genet 28, 69-75.

Bonadio, J., Jepsen, K.J., Mansoura, M.K., Jaenisch, R., Kuhn, J.L., and Goldstein, S.A. (1993). A murine skeletal adaptation that significantly increases cortical bone mechanical properties. Implications for human skeletal fragility. The Journal of clinical investigation 92, 1697-1705.

Boutaud, B., and Laville, J.M. (2004). [Elastic sliding central medullary nailing with osteogenesis imperfecta. Fourteen cases at eight years follow-up]. Rev Chir Orthop Reparatrice Appar Mot 90, 304-311.

Boyde, A., Travers, R., Glorieux, F.H., and Jones, S.J. (1999). The mineralization density of iliac crest bone from children with osteogenesis imperfecta. Calcified tissue international 64, 185-190.

Boyden, L.M., Mao, J., Belsky, J., Mitzner, L., Farhi, A., Mitnick, M.A., Wu, D., Insogna, K., and Lifton, R.P. (2002). High bone density due to a mutation in LDL-receptorrelated protein 5. The New England journal of medicine 346, 1513-1521. 
Breindl, M., Harbers, K., and Jaenisch, R. (1984). Retrovirus-induced lethal mutation in collagen I gene of mice is associated with an altered chromatin structure. Cell 38, 916.

Breslau-Siderius, E.J., Engelbert, R.H., Pals, G., and van der Sluijs, J.A. (1998). Bruck syndrome: a rare combination of bone fragility and multiple congenital joint contractures. Journal of pediatric orthopaedics 7, 35-38.

Brude, E. (1986). Ocular osteogenesis imperfecta. Clin Genet 29, 187.

Byers, P.H., Wallis, G.A., and Willing, M.C. (1991). Osteogenesis imperfecta: translation of mutation to phenotype. Journal of medical genetics 28, 433-442.

Cabral, W.A., Chang, W., Barnes, A.M., Weis, M., Scott, M.A., Leikin, S., Makareeva, E., Kuznetsova, N.V., Rosenbaum, K.N., Tifft, C.J., et al. (2007). Prolyl 3-hydroxylase 1 deficiency causes a recessive metabolic bone disorder resembling lethal/severe osteogenesis imperfecta. Nat Genet 39, 359-365.

Camacho, N.P., Landis, W.J., and Boskey, A.L. (1996). Mineral changes in a mouse model of osteogenesis imperfecta detected by Fourier transform infrared microscopy. Connect Tissue Res 35, 259-265.

Chang, W., Barnes, A.M., Cabral, W.A., Bodurtha, J.N., and Marini, J.C. (2009). Prolyl 3Hydroxylase 1 and CRTAP are Mutually Stabilizing in the Endoplasmic Reticulum Collagen Prolyl 3-Hydroxylation Complex. Human molecular genetics.

Chessler, S.D., Wallis, G.A., and Byers, P.H. (1993). Mutations in the carboxyl-terminal propeptide of the pro alpha 1(I) chain of type I collagen result in defective chain association and produce lethal osteogenesis imperfecta. The Journal of biological chemistry 268, 18218-18225.

Cheung, M.S., and Glorieux, F.H. (2008). Osteogenesis Imperfecta: update on presentation and management. Rev Endocr Metab Disord 9, 153-160.

Chipman, S.D., Sweet, H.O., McBride, D.J., Jr., Davisson, M.T., Marks, S.C., Jr., Shuldiner, A.R., Wenstrup, R.J., Rowe, D.W., and Shapiro, J.R. (1993). Defective pro alpha 2(I) collagen synthesis in a recessive mutation in mice: a model of human osteogenesis imperfecta. Proceedings of the National Academy of Sciences of the United States of America 90, 1701-1705.

Cho, T.J., Choi, I.H., Chung, C.Y., Yoo, W.J., Lee, K.S., and Lee, D.Y. (2007). Interlocking telescopic rod for patients with osteogenesis imperfecta. The Journal of bone and joint surgery American volume 89, 1028-1035.

Cho, T.J., Kim, J.B., Lee, J.W., Lee, K., Park, M.S., Yoo, W.J., Chung, C.Y., and Choi, I.H. (2011). Fracture in long bones stabilised by telescopic intramedullary rods in patients with osteogenesis imperfecta. J Bone Joint Surg Br 93, 634-638.

Choi, J.W., Sutor, S.L., Lindquist, L., Evans, G.L., Madden, B.J., Bergen, H.R., 3rd, Hefferan, T.E., Yaszemski, M.J., and Bram, R.J. (2009). Severe osteogenesis imperfecta in cyclophilin B-deficient mice. PLoS genetics 5, e1000750.

Christiansen, H.E., Schwarze, U., Pyott, S.M., AlSwaid, A., Al Balwi, M., Alrasheed, S., Pepin, M.G., Weis, M.A., Eyre, D.R., and Byers, P.H. (2010). Homozygosity for a missense mutation in SERPINH1, which encodes the collagen chaperone protein HSP47, results in severe recessive osteogenesis imperfecta. American journal of human genetics $86,389-398$. 
Chu, M.L., Williams, C.J., Pepe, G., Hirsch, J.L., Prockop, D.J., and Ramirez, F. (1983). Internal deletion in a collagen gene in a perinatal lethal form of osteogenesis imperfecta. Nature 304, 78-80.

Cohn, D.H., Starman, B.J., Blumberg, B., and Byers, P.H. (1990). Recurrence of lethal osteogenesis imperfecta due to parental mosaicism for a dominant mutation in a human type I collagen gene (COL1A1). American journal of human genetics 46, 591-601.

Dawson, D.W., Volpert, O.V., Gillis, P., Crawford, S.E., Xu, H., Benedict, W., and Bouck, N.P. (1999). Pigment epithelium-derived factor: a potent inhibitor of angiogenesis. Science 285, 245-248.

de Graaff, F., Verra, W., Pruijs, J.E., and Sakkers, R.J. (2011). Decrease in outpatient department visits and operative interventions due to bisphosphonates in children with osteogenesis imperfecta. J Child Orthop 5, 121-125.

De Paepe, A., Leroy, J.G., Nuytinck, L., Meire, F., and Capoen, J. (1993). Osteoporosispseudoglioma syndrome. American journal of medical genetics 45, 30-37.

Deak, S.B., van der Rest, M., and Prockop, D.J. (1985). Altered helical structure of a homotrimer of alpha 1(I)chains synthesized by fibroblasts from a variant of osteogenesis imperfecta. Coll Relat Res 5, 305-313.

Devogelaer, J.P., and Coppin, C. (2006). Osteogenesis imperfecta : current treatment options and future prospects. Treat Endocrinol 5, 229-242.

Doll, J.A., Stellmach, V.M., Bouck, N.P., Bergh, A.R., Lee, C., Abramson, L.P., Cornwell, M.L., Pins, M.R., Borensztajn, J., and Crawford, S.E. (2003). Pigment epitheliumderived factor regulates the vasculature and mass of the prostate and pancreas. Nat Med 9, 774-780.

Drogemuller, C., Becker, D., Brunner, A., Haase, B., Kircher, P., Seeliger, F., Fehr, M., Baumann, U., Lindblad-Toh, K., and Leeb, T. (2009). A missense mutation in the SERPINH1 gene in Dachshunds with osteogenesis imperfecta. PLoS genetics 5, e1000579.

Edwards, M.J., Wenstrup, R.J., Byers, P.H., and Cohn, D.H. (1992). Recurrence of lethal osteogenesis imperfecta due to parental mosaicism for a mutation in the COL1A2 gene of type I collagen. The mosaic parent exhibits phenotypic features of a mild form of the disease. Human mutation 1, 47-54.

el-Sobky, M.A., Hanna, A.A., Basha, N.E., Tarraf, Y.N., and Said, M.H. (2006). Surgery versus surgery plus pamidronate in the management of osteogenesis imperfecta patients: a comparative study. Journal of pediatric orthopaedics Part B / European Paediatric Orthopaedic Society, Pediatric Orthopaedic Society of North America 15, 222-228.

Enright, W.J., and Noonan, K.J. (2006). Bone plating in patients with type III osteogenesis imperfecta: results and complications. Iowa Orthop J 26, 37-40.

Esposito, P., and Plotkin, H. (2008). Surgical treatment of osteogenesis imperfecta: current concepts. Current opinion in pediatrics 20, 52-57.

Esposito, P.W. (2010). Multiple Percutaneous Osteotomies and Fassier-Duval Telescoping Nailing of Long Bone in Osteogenesis Imperfecta. In Operative Techniques in Orthopedic Surgery, S. Wiesel, ed. (Philadelphia, PA, Wolters Kluwer/Lippincott Williams \& Wilkins), pp. 1284-1294. 
Fassier, F., Esposito, P., Sponseller, P.D., and al., e. (2006). Multicenter radiological assessment of the Fassier-Duval femoral rodding. In Pediatric Orthopaedic Society of North America (San Diego, CA).

Fassier, F., and Glorieux, D.F. (2003). Osteogenesis Imperfecta. In Surgical Techniques in Orthopaedics and Traumatology (Elsevier).

Fedarko, N.S., Robey, P.G., and Vetter, U.K. (1995). Extracellular matrix stoichiometry in osteoblasts from patients with osteogenesis imperfecta. Journal of bone and mineral research : the official journal of the American Society for Bone and Mineral Research 10, 1122-1129.

Filleur, S., Nelius, T., de Riese, W., and Kennedy, R.C. (2009). Characterization of PEDF: a multi-functional serpin family protein. Journal of cellular biochemistry 106, 769775 .

Forin, V., Arabi, A., Guigonis, V., Filipe, G., Bensman, A., and Roux, C. (2005). Benefits of pamidronate in children with osteogenesis imperfecta: an open prospective study. Joint Bone Spine 72, 313-318.

Forlino, A., and al., e. (2005). Maturation or homozygosity modulates OI phenotype in BRTL mouse. In 9th International Meeting on Osteogenesis Imperfecta (Annapolis, MD).

Forlino, A., Cabral, W.A., Barnes, A.M., and Marini, J.C. (2011). New perspectives on osteogenesis imperfecta. Nat Rev Endocrinol 7, 540-557.

Forlino, A., Porter, F.D., Lee, E.J., Westphal, H., and Marini, J.C. (1999). Use of the Cre/lox recombination system to develop a non-lethal knock-in murine model for osteogenesis imperfecta with an alpha1(I) G349C substitution. Variability in phenotype in BrtlIV mice. The Journal of biological chemistry 274, 37923-37931.

Forlino, A., Tani, C., Rossi, A., Lupi, A., Campari, E., Gualeni, B., Bianchi, L., Armini, A., Cetta, G., Bini, L., et al. (2007). Differential expression of both extracellular and intracellular proteins is involved in the lethal or nonlethal phenotypic variation of BrtlIV, a murine model for osteogenesis imperfecta. Proteomics 7, 1877-1891.

Fratzl-Zelman, N., Morello, R., Lee, B., Rauch, F., Glorieux, F.H., Misof, B.M., Klaushofer, K., and Roschger, P. (2010). CRTAP deficiency leads to abnormally high bone matrix mineralization in a murine model and in children with osteogenesis imperfecta type VII. Bone 46, 820-826.

Frontali, M., and Dallapiccola, B. (1986). Osteoporosis-pseudoglioma syndrome and the ocular form of osteogenesis imperfecta. Clin Genet 29, 262.

Gargan, M.F., Wisbeach, A., and Fixsen, J.A. (1996). Humeral rodding in osteogenesis imperfecta. J Pediatr Orthop 16, 719-722.

Glorieux, F.H. (2007). Experience with bisphosphonates in osteogenesis imperfecta. Pediatrics 119 Suppl 2, S163-165.

Glorieux, F.H., Bishop, N.J., Plotkin, H., Chabot, G., Lanoue, G., and Travers, R. (1998). Cyclic administration of pamidronate in children with severe osteogenesis imperfecta. The New England journal of medicine 339, 947-952.

Glorieux, F.H., Rauch, F., Plotkin, H., Ward, L., Travers, R., Roughley, P., Lalic, L., Glorieux, D.F., Fassier, F., and Bishop, N.J. (2000). Type V osteogenesis imperfecta: a new form of brittle bone disease. J Bone Miner Res 15, 1650-1658. 
Glorieux, F.H., Ward, L.M., Rauch, F., Lalic, L., Roughley, P.J., and Travers, R. (2002). Osteogenesis imperfecta type VI: a form of brittle bone disease with a mineralization defect. J Bone Miner Res 17, 30-38.

Gong, Y., Slee, R.B., Fukai, N., Rawadi, G., Roman-Roman, S., Reginato, A.M., Wang, H., Cundy, T., Glorieux, F.H., Lev, D., et al. (2001). LDL receptor-related protein 5 (LRP5) affects bone accrual and eye development. Cell 107, 513-523.

Gong, Y., Vikkula, M., Boon, L., Liu, J., Beighton, P., Ramesar, R., Peltonen, L., Somer, H., Hirose, T., Dallapiccola, B., et al. (1996). Osteoporosis-pseudoglioma syndrome, a disorder affecting skeletal strength and vision, is assigned to chromosome region 11q12-13. American journal of human genetics 59, 146-151.

Gothel, S.F., and Marahiel, M.A. (1999). Peptidyl-prolyl cis-trans isomerases, a superfamily of ubiquitous folding catalysts. Cell Mol Life Sci 55, 423-436.

Guenet, J.L., Stanescu, R., Maroteaux, P., and Stanescu, V. (1981). Fragilitas ossium: a new autosomal recessive mutation in the mouse. J Hered 72, 440-441.

Ha-Vinh, R., Alanay, Y., Bank, R.A., Campos-Xavier, A.B., Zankl, A., Superti-Furga, A., and Bonafe, L. (2004). Phenotypic and molecular characterization of Bruck syndrome (osteogenesis imperfecta with contractures of the large joints) caused by a recessive mutation in PLOD2. American journal of medical genetics 131, 115-120.

Han, S., Makareeva, E., Kuznetsova, N.V., DeRidder, A.M., Sutter, M.B., Losert, W., Phillips, C.L., Visse, R., Nagase, H., and Leikin, S. (2010). Molecular mechanism of type I collagen homotrimer resistance to mammalian collagenases. The Journal of biological chemistry 285, 22276-22281.

Hartung, S., Jaenisch, R., and Breindl, M. (1986). Retrovirus insertion inactivates mouse alpha 1(I) collagen gene by blocking initiation of transcription. Nature 320, 365-367.

Hatz, D., Esposito, P.W., Schroeder, B., Burke, B., Lutz, R., and Hasley, B.P. (2011). The incidence of spondylolysis and spondylolisthesis in children with osteogenesis imperfecta. J Pediatr Orthop 31, 655-660.

Homan, E.P., Rauch, F., Grafe, I., Lietman, C., Doll, J.A., Dawson, B., Bertin, T., Napierala, D., Morello, R., Gibbs, R., et al. (2011). Mutations in SERPINF1 cause Osteogenesis imperfecta Type VI. Journal of bone and mineral research : the official journal of the American Society for Bone and Mineral Research.

Ishida, Y., Yamamoto, A., Kitamura, A., Lamande, S.R., Yoshimori, T., Bateman, J.F., Kubota, H., and Nagata, K. (2009). Autophagic elimination of misfolded procollagen aggregates in the endoplasmic reticulum as a means of cell protection. Molecular biology of the cell 20, 2744-2754.

Ishikawa, Y., Vranka, J., Wirz, J., Nagata, K., and Bachinger, H.P. (2008). The rough endoplasmic reticulum-resident FK506-binding protein FKBP65 is a molecular chaperone that interacts with collagens. J Biol Chem 283, 31584-31590.

Ishikawa, Y., Wirz, J., Vranka, J.A., Nagata, K., and Bachinger, H.P. (2009). Biochemical characterization of the prolyl 3-hydroxylase 1.cartilage-associated protein.cyclophilin B complex. J Biol Chem 284, 17641-17647.

Jaenisch, R., Harbers, K., Schnieke, A., Lohler, J., Chumakov, I., Jahner, D., Grotkopp, D., and Hoffmann, E. (1983). Germline integration of moloney murine leukemia virus at the Mov13 locus leads to recessive lethal mutation and early embryonic death. Cell 32, 209-216. 
Jiao, X., Ventruto, V., Trese, M.T., Shastry, B.S., and Hejtmancik, J.F. (2004). Autosomal recessive familial exudative vitreoretinopathy is associated with mutations in LRP5. American journal of human genetics 75, 878-884.

Joseph, B., Rebello, G., and B, C.K. (2005). The choice of intramedullary devices for the femur and the tibia in osteogenesis imperfecta. Journal of pediatric orthopaedics Part B / European Paediatric Orthopaedic Society, Pediatric Orthopaedic Society of North America 14, 311-319.

Kelley, B.P., Malfait, F., Bonafe, L., Baldridge, D., Homan, E., Symoens, S., Willaert, A., Elcioglu, N., Van Maldergem, L., Verellen-Dumoulin, C., et al. (2011). Mutations in FKBP10 cause recessive osteogenesis imperfecta and type 1 bruck syndrome. J Bone Miner Res.

Khavandgar, Z., Poirier, C., Clarke, C.J., Li, J., Wang, N., McKee, M.D., Hannun, Y.A., and Murshed, M. (2011). A cell-autonomous requirement for neutral sphingomyelinase 2 in bone mineralization. The Journal of cell biology 194, 277-289.

Khillan, J.S., Olsen, A.S., Kontusaari, S., Sokolov, B., and Prockop, D.J. (1991). Transgenic mice that express a mini-gene version of the human gene for type I procollagen (COL1A1) develop a phenotype resembling a lethal form of osteogenesis imperfecta. The Journal of biological chemistry 266, 23373-23379.

Kivirikko, K.I., and Pihlajaniemi, T. (1998). Collagen hydroxylases and the protein disulfide isomerase subunit of prolyl 4-hydroxylases. Adv Enzymol Relat Areas Mol Biol 72, 325-398.

Kozloff, K.M., Carden, A., Bergwitz, C., Forlino, A., Uveges, T.E., Morris, M.D., Marini, J.C., and Goldstein, S.A. (2004). Brittle IV mouse model for osteogenesis imperfecta IV demonstrates postpubertal adaptations to improve whole bone strength. Journal of bone and mineral research : the official journal of the American Society for Bone and Mineral Research 19, 614-622.

Kuznetsova, N., McBride, D.J., Jr., and Leikin, S. (2001). Osteogenesis imperfecta murine: interaction between type I collagen homotrimers. J Mol Biol 309, 807-815.

Labuda, M., Morissette, J., Ward, L.M., Rauch, F., Lalic, L., Roughley, P.J., and Glorieux, F.H. (2002). Osteogenesis imperfecta type VII maps to the short arm of chromosome 3. Bone 31, 19-25.

Land, C., Rauch, F., Montpetit, K., Ruck-Gibis, J., and Glorieux, F.H. (2006a). Effect of intravenous pamidronate therapy on functional abilities and level of ambulation in children with osteogenesis imperfecta. J Pediatr 148, 456-460.

Land, C., Rauch, F., Munns, C.F., Sahebjam, S., and Glorieux, F.H. (2006b). Vertebral morphometry in children and adolescents with osteogenesis imperfecta: effect of intravenous pamidronate treatment. Bone 39, 901-906.

Lapunzina, P., Aglan, M., Temtamy, S., Caparros-Martin, J.A., Valencia, M., Leton, R., Martinez-Glez, V., Elhossini, R., Amr, K., Vilaboa, N., et al. Identification of a frameshift mutation in Osterix in a patient with recessive osteogenesis imperfecta. American journal of human genetics 87, 110-114.

Law, R.H., Zhang, Q., McGowan, S., Buckle, A.M., Silverman, G.A., Wong, W., Rosado, C.J., Langendorf, C.G., Pike, R.N., Bird, P.I., et al. (2006). An overview of the serpin superfamily. Genome biology 7, 216. 
Lisse, T.S., Thiele, F., Fuchs, H., Hans, W., Przemeck, G.K., Abe, K., Rathkolb, B., Quintanilla-Martinez, L., Hoelzlwimmer, G., Helfrich, M., et al. (2008). ER stressmediated apoptosis in a new mouse model of osteogenesis imperfecta. PLoS genetics 4, e7.

Little, R.D., Carulli, J.P., Del Mastro, R.G., Dupuis, J., Osborne, M., Folz, C., Manning, S.P., Swain, P.M., Zhao, S.C., Eustace, B., et al. (2002). A mutation in the LDL receptorrelated protein 5 gene results in the autosomal dominant high-bone-mass trait. American journal of human genetics 70, 11-19.

Luhmann, S.J., Sheridan, J.J., Capelli, A.M., and Schoenecker, P.L. (1998). Management of lower-extremity deformities in osteogenesis imperfecta with extensible intramedullary rod technique: a 20 -year experience. J Pediatr Orthop 18, 88-94.

Makareeva, E., Aviles, N.A., and Leikin, S. (2011). Chaperoning osteogenesis: new proteinfolding disease paradigms. Trends Cell Biol 21, 168-176.

Malfait, F., Symoens, S., Coucke, P., Nunes, L., De Almeida, S., and De Paepe, A. (2006). Total absence of the alpha2(I) chain of collagen type I causes a rare form of EhlersDanlos syndrome with hypermobility and propensity to cardiac valvular problems. Journal of medical genetics 43, e36.

Marini, J.C., Cabral, W.A., and Barnes, A.M. (2010). Null mutations in LEPRE1 and CRTAP cause severe recessive osteogenesis imperfecta. Cell and tissue research 339, 59-70.

Marini, J.C., Forlino, A., Cabral, W.A., Barnes, A.M., San Antonio, J.D., Milgrom, S., Hyland, J.C., Korkko, J., Prockop, D.J., De Paepe, A., et al. (2007). Consortium for osteogenesis imperfecta mutations in the helical domain of type I collagen: regions rich in lethal mutations align with collagen binding sites for integrins and proteoglycans. Human mutation 28, 209-221.

Martin, E., and Shapiro, J.R. (2007). Osteogenesis imperfecta:epidemiology and pathophysiology. Current osteoporosis reports 5, 91-97.

Meyer, C., Notari, L., and Becerra, S.P. (2002). Mapping the type I collagen-binding site on pigment epithelium-derived factor. Implications for its antiangiogenic activity. The Journal of biological chemistry 277, 45400-45407.

Montpetit, K., Plotkin, H., Rauch, F., Bilodeau, N., Cloutier, S., Rabzel, M., and Glorieux, F.H. (2003). Rapid increase in grip force after start of pamidronate therapy in children and adolescents with severe osteogenesis imperfecta. Pediatrics 111, e601603.

Morello, R., Bertin, T.K., Chen, Y., Hicks, J., Tonachini, L., Monticone, M., Castagnola, P., Rauch, F., Glorieux, F.H., Vranka, J., et al. (2006). CRTAP is required for prolyl 3hydroxylation and mutations cause recessive osteogenesis imperfecta. Cell 127, 291-304.

Nagai, N., Hosokawa, M., Itohara, S., Adachi, E., Matsushita, T., Hosokawa, N., and Nagata, K. (2000). Embryonic lethality of molecular chaperone hsp47 knockout mice is associated with defects in collagen biosynthesis. The Journal of cell biology 150, 1499-1506.

Nakashima, K., Zhou, X., Kunkel, G., Zhang, Z., Deng, J.M., Behringer, R.R., and de Crombrugghe, B. (2002). The novel zinc finger-containing transcription factor osterix is required for osteoblast differentiation and bone formation. Cell 108, 17-29. 
Nicholls, A.C., Valler, D., Wallis, S., and Pope, F.M. (2001). Homozygosity for a splice site mutation of the COL1A2 gene yields a non-functional pro(alpha)2(I) chain and an EDS/OI clinical phenotype. Journal of medical genetics 38, 132-136.

Patterson, C.E., Abrams, W.R., Wolter, N.E., Rosenbloom, J., and Davis, E.C. (2005). Developmental regulation and coordinate reexpression of FKBP65 with extracellular matrix proteins after lung injury suggest a specialized function for this endoplasmic reticulum immunophilin. Cell stress \& chaperones 10, 285-295.

Pemberton, T.J., and Kay, J.E. (2005). Identification and comparative analysis of the peptidyl-prolyl cis/trans isomerase repertoires of H. sapiens, D. melanogaster, C. elegans, S. cerevisiae and Sz. pombe. Comparative and functional genomics 6, 277300.

Pereira, R., Khillan, J.S., Helminen, H.J., Hume, E.L., and Prockop, D.J. (1993). Transgenic mice expressing a partially deleted gene for type I procollagen (COL1A1). A breeding line with a phenotype of spontaneous fractures and decreased bone collagen and mineral. The Journal of clinical investigation 91, 709-716.

Pizones, J., Plotkin, H., Parra-Garcia, J.I., Alvarez, P., Gutierrez, P., Bueno, A., and Fernandez-Arroyo, A. (2005). Bone healing in children with osteogenesis imperfecta treated with bisphosphonates. J Pediatr Orthop 25, 332-335.

Plotkin, H. (2004). Syndromes with congenital brittle bones. BMC Pediatr 4, 16.

Plotkin, H., Coughlin, S., Kreikemeier, R., Luksan, M., and Esposito, P. (2006). Low Doses of Pamidronate for Children with Osteogenesis Imperfecta (OI). Paper presented at: Proceedings of the 28th Annual Meeting of the American Society for Bone and Mineral Research (Philadelphia, PA, JBMR).

Rauch, F., Cornibert, S., Cheung, M., and Glorieux, F.H. (2007). Long-bone changes after pamidronate discontinuation in children and adolescents with osteogenesis imperfecta. Bone 40, 821-827.

Rauch, F., and Glorieux, F.H. (2004). Osteogenesis imperfecta. Lancet 363, 1377-1385.

Rauch, F., and Glorieux, F.H. (2006). Treatment of children with osteogenesis imperfecta. Current osteoporosis reports 4, 159-164.

Rauch, F., Munns, C., Land, C., and Glorieux, F.H. (2006). Pamidronate in children and adolescents with osteogenesis imperfecta: effect of treatment discontinuation. The Journal of clinical endocrinology and metabolism 91, 1268-1274.

Roschger, P., Fratzl-Zelman, N., Misof, B.M., Glorieux, F.H., Klaushofer, K., and Rauch, F. (2008a). Evidence that abnormal high bone mineralization in growing children with osteogenesis imperfecta is not associated with specific collagen mutations. Calcified tissue international $82,263-270$.

Roschger, P., Paschalis, E.P., Fratzl, P., and Klaushofer, K. (2008b). Bone mineralization density distribution in health and disease. Bone 42, 456-466.

Roussel, B.D., Irving, J.A., Ekeowa, U.I., Belorgey, D., Haq, I., Ordonez, A., Kruppa, A.J., Duvoix, A., Rashid, S.T., Crowther, D.C., et al. (2011). Unravelling the twists and turns of the serpinopathies. The FEBS journal 278, 3859-3867.

Rutkowski, D.T., Arnold, S.M., Miller, C.N., Wu, J., Li, J., Gunnison, K.M., Mori, K., Sadighi Akha, A.A., Raden, D., and Kaufman, R.J. (2006). Adaptation to ER stress is mediated by differential stabilities of pro-survival and pro-apoptotic mRNAs and proteins. PLoS Biol 4, e374. 
Schnieke, A., Harbers, K., and Jaenisch, R. (1983). Embryonic lethal mutation in mice induced by retrovirus insertion into the alpha 1(I) collagen gene. Nature 304, 315320.

Schwarze, U., Hata, R., McKusick, V.A., Shinkai, H., Hoyme, H.E., Pyeritz, R.E., and Byers, P.H. (2004). Rare autosomal recessive cardiac valvular form of Ehlers-Danlos syndrome results from mutations in the COL1A2 gene that activate the nonsensemediated RNA decay pathway. American journal of human genetics 74, 917-930.

Shapiro, J.R., and Sponsellor, P.D. (2009). Osteogenesis imperfecta: questions and answers. Current opinion in pediatrics 21, 709-716.

Sillence, D.O. (1988). Osteogenesis imperfecta nosology and genetics. Ann N Y Acad Sci 543, $1-15$.

Sillence, D.O., Ritchie, H.E., Dibbayawan, T., Eteson, D., and Brown, K. (1993). Fragilitas ossium (fro/fro) in the mouse: a model for a recessively inherited type of osteogenesis imperfecta. American journal of medical genetics 45, 276-283.

Sillence, D.O., Senn, A., and Danks, D.M. (1979). Genetic heterogeneity in osteogenesis imperfecta. Journal of medical genetics 16, 101-116.

Stacey, A., Bateman, J., Choi, T., Mascara, T., Cole, W., and Jaenisch, R. (1988). Perinatal lethal osteogenesis imperfecta in transgenic mice bearing an engineered mutant pro-alpha 1(I) collagen gene. Nature 332, 131-136.

Sulko, J., and Radlo, W. (2005). [Operative management of long-bone of the upper limb in children with osteogenesis imperfecta]. Chir Narzadow Ruchu Ortop Pol 70, 195199.

Superti-Furga, A., Steinmann, B., and Perfumo, F. (1986). Osteoporosis-pseudoglioma or osteogenesis imperfecta? Clin Genet 29, 184-185.

Toomes, C., Bottomley, H.M., Jackson, R.M., Towns, K.V., Scott, S., Mackey, D.A., Craig, J.E., Jiang, L., Yang, Z., Trembath, R., et al. (2004). Mutations in LRP5 or FZD4 underlie the common familial exudative vitreoretinopathy locus on chromosome 11q. American journal of human genetics 74, 721-730.

Tryon, R.C., White, S.D., and Bannasch, D.L. (2007). Homozygosity mapping approach identifies a missense mutation in equine cyclophilin B (PPIB) associated with HERDA in the American Quarter Horse. Genomics 90, 93-102.

Tsang, K.S., and Adedapo, A. (2011). Cannulated screw fixation of fracture neck of femur in children with osteogenesis imperfecta. Journal of pediatric orthopaedics Part B / European Paediatric Orthopaedic Society, Pediatric Orthopaedic Society of North America 20, 287-290.

Tsang, K.Y., Chan, D., Bateman, J.F., and Cheah, K.S. (2010). In vivo cellular adaptation to ER stress: survival strategies with double-edged consequences. Journal of cell science 123, 2145-2154.

Turman, K., Esposito, P., Plotkin, H., and al., e. (2006). Initial results with Fassier-Duval telescoping rods in osteogenesis imperfecta. In Pediatric Orthopaedic Society of North America (San Diego, CA).

Valli, M., Barnes, A.M., Gallanti, A., Cabral, W.A., Viglio, S., Weis, M., Makareeva, E., Eyre, D., Leikin, S., Antoniazzi, F., et al. (2011). Deficiency of CRTAP in Non-lethal Recessive Osteogenesis Imperfecta Reduces Collagen Deposition into Matrix. Clin Genet. 
van der Slot, A.J., Zuurmond, A.M., Bardoel, A.F., Wijmenga, C., Pruijs, H.E., Sillence, D.O., Brinckmann, J., Abraham, D.J., Black, C.M., Verzijl, N., et al. (2003). Identification of PLOD2 as telopeptide lysyl hydroxylase, an important enzyme in fibrosis. J Biol Chem 278, 40967-40972.

van Dijk, F.S., Nesbitt, I.M., Zwikstra, E.H., Nikkels, P.G., Piersma, S.R., Fratantoni, S.A., Jimenez, C.R., Huizer, M., Morsman, A.C., Cobben, J.M., et al. (2009). PPIB mutations cause severe osteogenesis imperfecta. American journal of human genetics 85, 521-527.

Van Dijk, F.S., Pals, G., Van Rijn, R.R., Nikkels, P.G., and Cobben, J.M. (2010). Classification of Osteogenesis Imperfecta revisited. European journal of medical genetics 53, 1-5.

van Gent, D., Sharp, P., Morgan, K., and Kalsheker, N. (2003). Serpins: structure, function and molecular evolution. Int J Biochem Cell Biol 35, 1536-1547.

Van Wesenbeeck, L., Cleiren, E., Gram, J., Beals, R.K., Benichou, O., Scopelliti, D., Key, L., Renton, T., Bartels, C., Gong, Y., et al. (2003). Six novel missense mutations in the LDL receptor-related protein 5 (LRP5) gene in different conditions with an increased bone density. American journal of human genetics 72, 763-771.

Vranka, J.A., Pokidysheva, E., Hayashi, L., Zientek, K., Mizuno, K., Ishikawa, Y., Maddox, K., Tufa, S., Keene, D.R., Klein, R., et al. (2010). Prolyl 3-hydroxylase 1 null mice display abnormalities in fibrillar collagen-rich tissues such as tendons, skin and bones. J Biol Chem.

Vranka, J.A., Sakai, L.Y., and Bachinger, H.P. (2004). Prolyl 3-hydroxylase 1: Enzyme characterization and identification of a novel family of enzymes. J Biol Chem.

Ward, K.A., Adams, J.E., Freemont, T.J., and Mughal, M.Z. (2007). Can bisphosphonate treatment be stopped in a growing child with skeletal fragility? Osteoporosis international : a journal established as result of cooperation between the European Foundation for Osteoporosis and the National Osteoporosis Foundation of the USA $18,1137-1140$.

Ward, L.M., Rauch, F., Travers, R., Chabot, G., Azouz, E.M., Lalic, L., Roughley, P.J., and Glorieux, F.H. (2002). Osteogenesis imperfecta type VII: an autosomal recessive form of brittle bone disease. Bone 31, 12-18.

Warman, M.L., Cormier-Daire, V., Hall, C., Krakow, D., Lachman, R., LeMerrer, M., Mortier, G., Mundlos, S., Nishimura, G., Rimoin, D.L., et al. (2011). Nosology and classification of genetic skeletal disorders: 2010 revision. American journal of medical genetics Part A 155A, 943-968.

Willaert, A., Malfait, F., Symoens, S., Gevaert, K., Kayserili, H., Megarbane, A., Mortier, G., Leroy, J.G., Coucke, P.J., and De Paepe, A. (2009). Recessive osteogenesis imperfecta caused by LEPRE1 mutations: clinical documentation and identification of the splice form responsible for prolyl 3-hydroxylation. Journal of medical genetics 46, 233-241.

Willing, M.C., Pruchno, C.J., Atkinson, M., and Byers, P.H. (1992). Osteogenesis imperfecta type I is commonly due to a COL1A1 null allele of type I collagen. American journal of human genetics 51, 508-515.

Yao, Q., Li, M., Yang, H., Chai, H., Fisher, W., and Chen, C. (2005). Roles of cyclophilins in cancers and other organ systems. World journal of surgery 29, 276-280. 
Zhou, X., Zhang, Z., Feng, J.Q., Dusevich, V.M., Sinha, K., Zhang, H., Darnay, B.G., and de Crombrugghe, B. (2010). Multiple functions of Osterix are required for bone growth and homeostasis in postnatal mice. Proc Natl Acad Sci U S A 107, 12919-12924. 


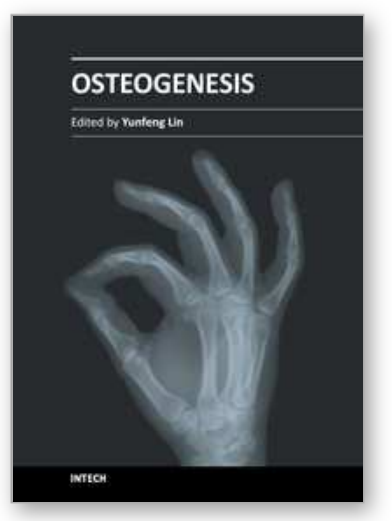

\author{
Osteogenesis \\ Edited by Prof. Yunfeng Lin
}

ISBN 978-953-51-0030-0

Hard cover, 296 pages

Publisher InTech

Published online 10, February, 2012

Published in print edition February, 2012

This book provides an in-depth overview of current knowledge about Osteogenesis, including molecular mechanisms, transcriptional regulators, scaffolds, cell biology, mechanical stimuli, vascularization and osteogenesis related diseases. Hopefully, the publication of this book will help researchers in this field to decide where to focus their future efforts, and provide an overview for surgeons and clinicians who wish to be directed in the developments related to this fascinating subject.

\title{
How to reference
}

In order to correctly reference this scholarly work, feel free to copy and paste the following:

Roy Morello and Paul W. Esposito (2012). Osteogenesis Imperfecta, Osteogenesis, Prof. Yunfeng Lin (Ed.), ISBN: 978-953-51-0030-0, InTech, Available from:

http://www.intechopen.com/books/osteogenesis/osteogenesis-imperfecta

\section{INTECH}

open science | open minds

\author{
InTech Europe \\ University Campus STeP Ri \\ Slavka Krautzeka 83/A \\ 51000 Rijeka, Croatia \\ Phone: +385 (51) 770447 \\ Fax: +385 (51) 686166 \\ www.intechopen.com
}

\author{
InTech China \\ Unit 405, Office Block, Hotel Equatorial Shanghai \\ No.65, Yan An Road (West), Shanghai, 200040, China \\ 中国上海市延安西路65号上海国际贵都大饭店办公楼 405 单元 \\ Phone: +86-21-62489820 \\ Fax: $+86-21-62489821$
}


(C) 2012 The Author(s). Licensee IntechOpen. This is an open access article distributed under the terms of the Creative Commons Attribution 3.0 License, which permits unrestricted use, distribution, and reproduction in any medium, provided the original work is properly cited. 